\title{
Phylogenetic relationship and evolution of Neodidymelliopsis isolates collected from Iran
}

\author{
Soleimani $\mathbf{P}^{1}$, Soleimani $\mathbf{M J}^{1^{*}}$ and Hosseini $\mathbf{S}^{2}$ \\ ${ }^{I}$ Department of Plant Protection, College of Agriculture, Bu-Ali Sina University, Hamedan, Iran \\ ${ }^{2}$ Department of Plant Protection, College of Agriculture, Vali-e-Asr University of Rafsanjan, Rafsanjan, Iran
}

Soleimani P, Soleimani MJ, Hosseini S 2018 - Phylogenetic relationship and evolution of Neodidymelliopsis isolates collected from Iran. Mycosphere 9(6), 1235-1255, Doi 10.5943/mycosphere/9/6/12

\begin{abstract}
Several isolates of the novel genus Neodidymelliopsis have been recently found in Iranian citrus orchards with severe dieback symptoms. Neodidymelliopsis belongs to Didymellaceae, an important family of Pleosporales, Dothideomycetes. None of the few studies on molecular dating of Ascomycetes have resolved the divergence time of genera in Didymellaceae. Motivated by this fact, we consider the reliable age of a fossil related to extant species of Aigilalus, the estimated mean crown age of Dothideomycetes from other studies as a secondary calibration, also the second fossil which represent common ancestor of Capnodiales to calibrate the reconstructed tree. Our dating analysis is based on four genetic regions of 91 taxa from Capnodiales and Pleosporales, using BEAST analysis. The selected taxa of Pleosporales belong to Aigialaceae and Didymellaceae; including three newly discovered Neodidymelliopsis sp. isolates and one isolate of Didymella sp. from Iran. Our dating analyses suggest that Didymellaceae diverged from Aigialaceae in the Cretaceous, and initial divergence of Didymellaceae happened in the late Eocene followed by two divergences in the late Oligocene and several splits in the Miocene. Furthermore, the results suggest that the Iranian isolates of Neodidymelliopsis sp. and Didymella sp. diverged from other Neodidymelliopsis and Didymella isolates in the Pliocene and the late Miocene, respectively.
\end{abstract}

Key words - Didymellaceae - Divergence time - Fossil - Pleosporales - Secondary calibration

\section{Introduction}

Coelomycetes are a form-class of fungi which produce their conidia and conidiophore within the cavity like pycnidia (globose to pyriform conidiomata from which the conidia arise throughout an apical opening) or sporocarp (de Gruyter et al. 2009, Chen et al. 2015). This form-class of fungi consists of numerous endophytic, pathogenic or saprobic fungi in terrestrial and marine ecosystems, or in plants and animals (Dai et al. 2014, Hyde et al. 2014, Wijayawardene et al. 2016).

Coelomycetous fungi has been recently assigned to different phylogenetic groups, e.g. Dothideomycetes, Leotiomycetes and Sordariomycetes (Wijayawardene et al. 2016, 2017). Dothideomycetes is well-known class of Ascomycota (Wijayawardene et al. 2017, 2018), while Pleosporales contains a quarter of the class (Kirk et al. 2008), with Didymellaceae as the largest family in this order. Didymellaceae encompasses more than 5,400 taxa in MycoBank (Crous et al. 2004, Crous \& Groenewald 2017, Hashimoto et al. 2017). In the recent revision of Didymellaceae, 
26 genera belong to this family have been reported (Chen et al. 2015, 2017, Valenzuela-Lopez et al. 2018). Members of this family are pathogenic on a wide range of host plants, which mainly cause leaf and stem lesions and some are of quarantine significance (Aveskamp et al. 2008, Boehm et al. 2009, Chen et al. 2017). Recently, some isolates of the novel genus Neodidymelliopsis and Didymella have been found on the citrus trees with severe dieback symptoms in Iran. This motivated our research to find out the divergence time of the selected isolates of Didymellaceae, particularly, isolates of Neodidymelliopsis sp. and Didymella collected from southern parts of Iran by comparing their nucleotide sequences. To achieve this aim, we adopted a molecular dating approach based on the molecular clock hypothesis $(\mathrm{MCH})$, proposed by Zuckerkandl \& Pauling (1965).

Molecular dating combines information from the fossils, recorded events, geological events and those achieved from data analyses to estimate the age of clades in a phylogenetic tree (Rutschmann 2006, Ho \& Duchene 2014). It is also possible to use the estimated age of a node from previous studies to calibrate the molecular clock in a new study, as a secondary calibration (dos Reis et al. 2015). Recently, several molecular dating studies have tried to estimate the age of fungi based on the available fossils (Vijaykrishna et al. 2006, Beimforde et al. 2014, Hongsanan et al. 2016, Zhao et al. 2016, Hyde et al. 2017, Liu et al. 2017). However, lack of the reliable fossils is a limited factor in molecular dating studies, which could face even a bigger challenge when the microscopic structure of fungi is unknown (Prieto \& Wedin 2013).

Here, we first constructed a phylogenetic tree based on four multi-gene datasets including the four sequenced isolates and some taxa of Didymellaceae obtained from the National Center for Biotechnology Information (NCBI) databases. We performed the dating analysis which updated the age of Dothideomycetes, Pleosporales and gave the first estimation of the divergence time of Didymellaceae genera.

\section{Materials \& Methods}

\section{Sample collection, DNA extraction and sequencing}

We collected citrus samples with dieback, blight of vigorously growing shoots symptoms, from citrus orchards in three southern provinces of Iran (Kerman, Hormozgan and Khuzestan). Pathogen isolation and inoculum preparation were performed according to the methods described by Taylor \& Hyde (2003). Pure cultures were obtained by single spore isolation methods (Chomnunti et al. 2014). Four isolates were deposited at Centraalbureau voor Schimmelcultures (CBS) Fungal Biodiversity Center in the Netherlands and Iranian Fungal Culture Collection (IRAN.C) at the Iranian Research Institute of Plant Protection (Supplementary table 1).

The genomic DNA was extracted using Doyle \& Doyle (1987) protocol from the fungal mycelium produced in Potato Dextrose Agar (PDA) media at $25-27^{\circ} \mathrm{C}$ for 4 weeks. We amplified four genomic regions including partial large subunit nuclear rDNA (28S, LSU), internal transcribed spacer regions $1 \& 2$ and intervening 5.8S nrDNA (ITS), partial RNA polymerase II second largest subunit (RPB2) and partial beta-tubulin (TUB2) region using special primers (Table 1), as it was described by Chen et al. (2015). PCR products were visualized under UV light after electrophoresis in a $1.0 \%(\mathrm{w} / \mathrm{v})$ agarose gel containing $0.1 \mathrm{ug} / \mathrm{mL}$ ethidium bromide in $1 \times$ TAE buffer. Sanger sequencing was performed by Macrogen Company (Seoul, Korea), and results were submitted to NCBI (Supplementary table 1).

\section{Sequence alignment and phylogenetic analysis}

To determine the phylogenetic relationship of the selected Iranian isolates with the other available taxa, we considered LSU, RPB2, TUB2 and ITS genomic regions in all 26 accepted Didymellaceae genera, as mentioned by Valenzuela-Lopez et al. (2018). In addition, we used seven Aigialus and Capnodiales isolates; according to Beimforde et al. (2014), Phukhamsakda et al. (2016) as the out-group. The selected strains and their accession numbers were listed in Supplementary table 2. The genetic regions were separately aligned by MAFFT v.7 (Katoh \& 
Standley 2013). We checked the alignment visually and adjusted it manually in Mesquite v.3.04 (Maddison \& Maddison 2015). The alignments were concatenated by SequenceMatrix program (Vaidya et al. 2011). Linux version of IQ-tree tool v.1.6 (Nguyen et al. 2014) was used to reconstruct the phylogenetic trees and find the best substitution model. We assessed the reliability of the reconstructed branches by Bootstrap analyses on 1000 replicates, and visualized trees in FigTree v.1.4.2.

Table 1 Primers used in this study.

\begin{tabular}{lll}
\hline Regions & Primer pairs & Reference \\
\hline ITS & V9G/ITS4 & White et al. (1990), de Hoog \& Gerrits van den Ende (1998) \\
RPB2 & RPB2-5F2/fRPB2-7cR & Liu et al. (1999), Sung et al. (2007) \\
LSU & LR0R/LR7 & Vilgalys \& Hester (1990), Rehner \& Samuels (1994) \\
TUB2 & Btub2Fd/Btub4Rd & Woudenberg et al. (2009) \\
\hline
\end{tabular}

\section{Node Calibrations}

To calibrate the nodes, we took advantage of the age of the reliable fossils and the estimated mean crown age of Dothideomycetes. We compared three calibration scenarios, based on the minimum age of reliable fossils from the literature and the secondary calibration. The calibration based on the age of a node estimated in other study is referred to as secondary calibration (Ho \& Duchene 2014, dos Reis et al. 2015). In all cases, we considered Pleosporales as a monophyletic group.

In scenario I, we used a fossil of Margaretbarromyces dictyosporus (Fossil I) which belongs to Pleosporales with the age of 35-55 Mya (Mindell et al. 2007, Berbee \& Taylor 2010, Phukhamsakda et al. 2016). Since morphologically this fungus resembles Aigialus belonging to Aigialaceae, Pleosporales (Phukhamsakda et al. 2016), we assigned the estimated age of the fossil to the node of Aigialus cluster (AIG). To demonstrate the uncertainty of the fossil age we represented it by a lognormal distribution with an offset (minimum bound), because we did not have any information about the maximum bound of the age (Ho \& Philips 2009), with the mean of TMRCA (the most recent common ancestor) of Aigialus $=35, \mathrm{SD}=3.5$, offset $=34$, giving 95\% credibility interval (CI) of 58.

In scenario II, we used two fossils viz. M. dictyosporus to calibrate AIG node and a Metacapnodiaceae fossil ( 100-113 Mya, Schmidt et al. 2014) to calibrate the crown node of Capnodiales (CAP). In this scenario, we used the same setting as scenario I for M. dictyosporus fossil, while used a lognormal distribution (mean $=100, \mathrm{SD}=4.5$, offset $=99, \mathrm{CI}=120$ ) for the Metacapnodiaceae fossil.

For scenario III, besides the age of two pre-mentioned fossils, we considered the estimated mean crown age of Dothideomycetes (107-459 Mya) on the root of the tree estimated by Gueidan et al. (2011), Prieto \& Wedin (2013), Beimforde et al. (2014), Pérez-Ortega et al. (2016), Phukhamsakda et al. (2016) as a secondary calibration. We preferred a uniform distribution (with maximum of 457 and minimum of 107) for the secondary calibration, as simulation studies (Schenk 2016) reported that the normal prior distribution results in larger errors, compared to uniform distribution in the secondary calibrations. Fig. 1 illustrates the posterior probability density distribution of the three calibration points.

\section{Molecular dating}

We used the BEAST v1.8.2 package (Drummond et al. 2012) for the molecular dating analysis. For this analysis, we used an uncorrelated lognormal relaxed clock model (UCLD) and the simplest model, Yule process (Drummond \& Bouckaert 2014). GTR substitution model, 4 rate categories were used based on the suggestion from the model finder of IQ-tree. Since Gamma and invariable sites have a mutual effect (Drummond \& Bouckaert 2014, Moran et al. 2015), applying both on a model is not biologically meaningful (Jia et al. 2014). Hence, we excluded invariable sites from the substitution model and set up the mean rate to the continuous-time Markov chains 
model (CTMCs), recommended by Ferreira \& Suchard (2008). We performed three MCMC analyses of 400 million generations, with sampling every 10000 steps. The results were evaluated by Tracer v1.6. The effective sample size (ESS) values of parameters were checked and improved to be more than 200 (Drummond \& Bouckaert 2014). The resulted log and tree files were combined using LogCombiner1.8.0. Finally, we summarized the BEAST results by TreeAnnotator v1.4.7 with a burn-in of $10 \%$ and displayed them in FigTree v.1.4.2.

To compare different scenarios, we estimated the marginal likelihood (MLE) using path sampling (PS) and stepping stone sampling (SS), implemented in BEAST.

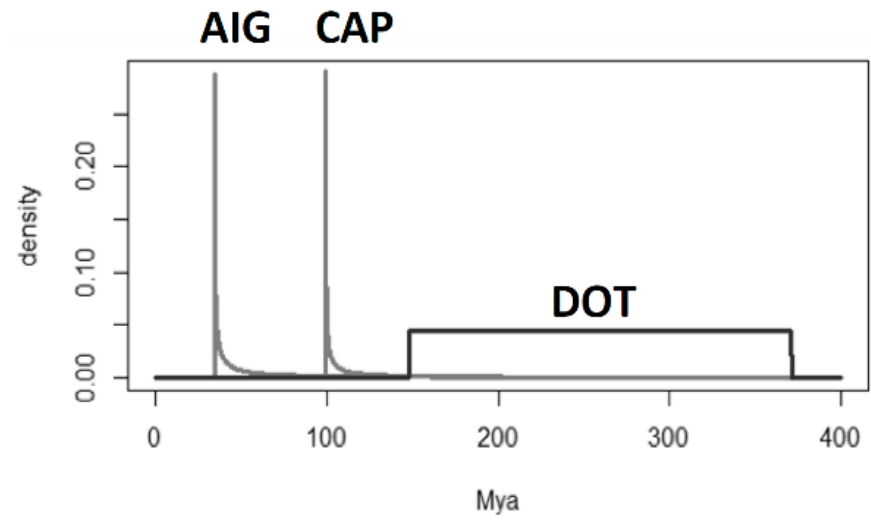

Figure 1 - The plot posterior probability density distribution of used calibration points. The AIG, CAP and DOT curves show the probability of used calibration points assigned to MRCA of Aigialus, Capnodiales and Dothideomycetes nodes respectively.

\section{Results}

\section{Phylogenetic analysis}

The concatenated file produced by SequenceMatrix, adjusted in Mesquite, contained 91 taxa with 2,864 characters. Fig. 2 summarizes the results of our phylogenetic analyses; the four sequenced taxa have been marked with black diamonds. IR67 isolate clustered with Didymella glomerata CBS 528.66, while IR10, IR26 and IR14 isolates clustered with Neodidymelliopsis longicolla CBS 382.96 with high bootstrap supports (99-100).

\section{Molecular dating analysis}

\section{Comparing different scenarios}

To compare different scenarios, we estimated the marginal likelihood (Table 2) which was slightly higher in scenario III, compared with the other scenarios.

\section{Divergence time}

The constructed trees in all scenarios (Fig. 4, Supplementary figs 1,2) were consistent to the best tree built by IQ-tree (Fig. 2). Most of the estimated mean of nodes are supported by a strong posterior probability. The crown and stem age of all nodes in scenario III are considered as the best scenario (see discussion, Table 3). Pleosporales diverged from Capnodiales at 144.5 (107-202.9) Mya. Within Pleosporales, Didymellaceae diverged from Aigialaceae at 86.7 (53.9-155.4) Mya. The mean age of the earliest split in Didymellaceae (Neoascochyta from other genera) is $\sim 35.7$ (18.4-63.5) Mya. The newest split of Briansuttonomyces and Pseudoascochyta from other genera in Didymellaceae occurred at $\sim 6.3(2-13.2)$ Mya. Iranian isolates of Neodidymelliopsis sp. and Didymella sp. diverged from other Neodidymelliopsis and Didymella isolates at $3.1(0.9-6.9)$ and 
8.6 (3.5-16.8) Mya, respectively (Fig. 4). Time charts of the nodes based on the estimated crown and stem ages in this student can be seen in Supplementary tables 4, 5 .

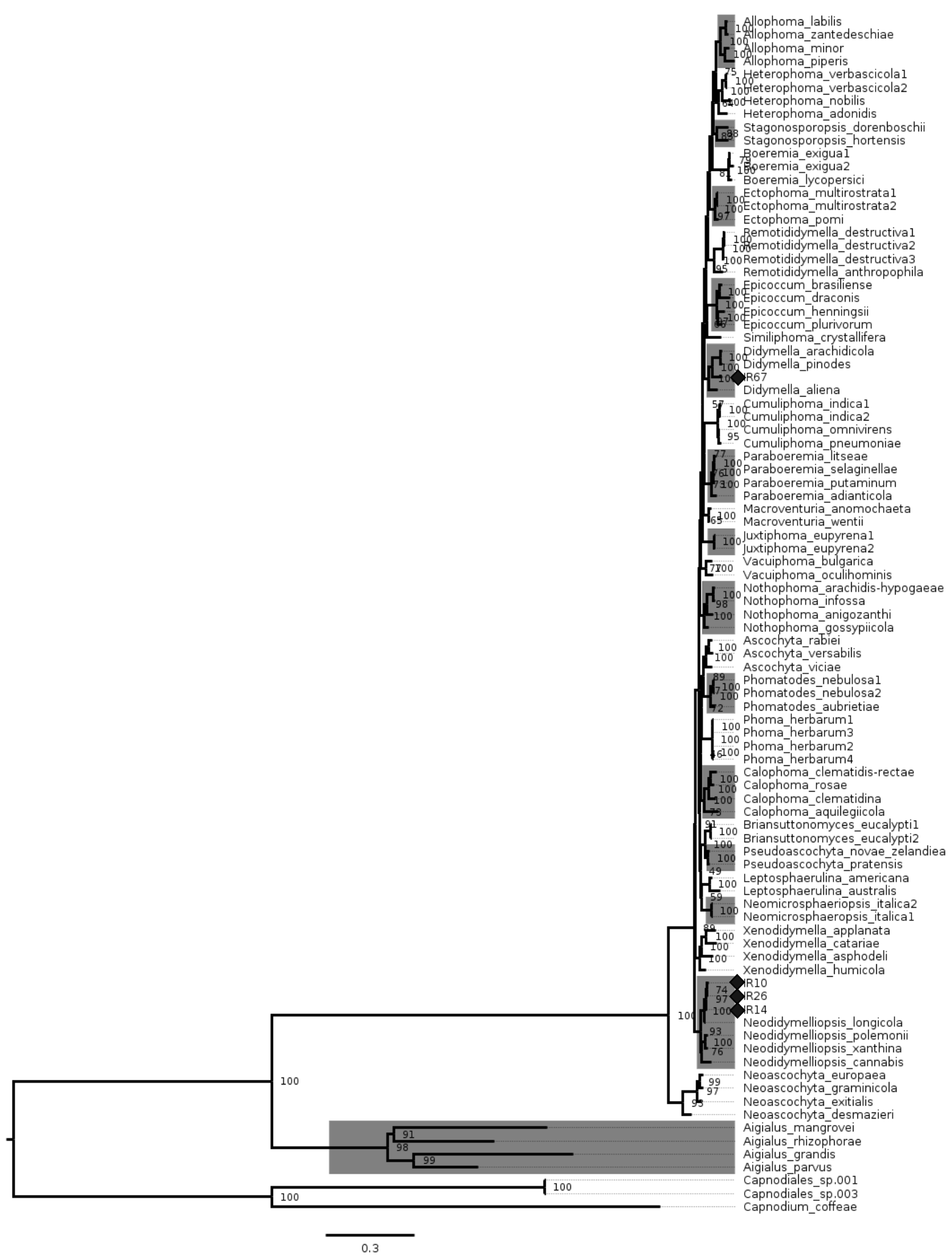

Figure 2 - The result of phylogenetic analyses. Bootstrap values are shown next to the nodes and the Iranian isolates are marked with black diamonds. 
Table 2 The estimated marginal likelihood in different models.

\begin{tabular}{lll}
\hline Scenario & $\begin{array}{l}\text { Log } \\
\text { (Marginal likelihood) } \\
\text { with SS }\end{array}$ & $\begin{array}{l}\text { Log } \\
\text { (Marginal likelihood) } \\
\text { with PS }\end{array}$ \\
\hline I & -26647.1 & -26647.4 \\
II & -26646.0 & -26645.3 \\
III & -26643.7 & -26643.6 \\
\hline
\end{tabular}

The comparison between the 95\% HPD (Highest Posterior Density) of four main nodes, MRCA of Dothideomycetes (DOT), Didymellaceae (DID), Pleosporales (PLE) and Neodidymelliopsis (NEO) nodes showed that the intervals of the defined scenarios are overlapped (Fig. 3). In Table 3, estimated age of crown nodes and interval of 95\% HPD are listed.

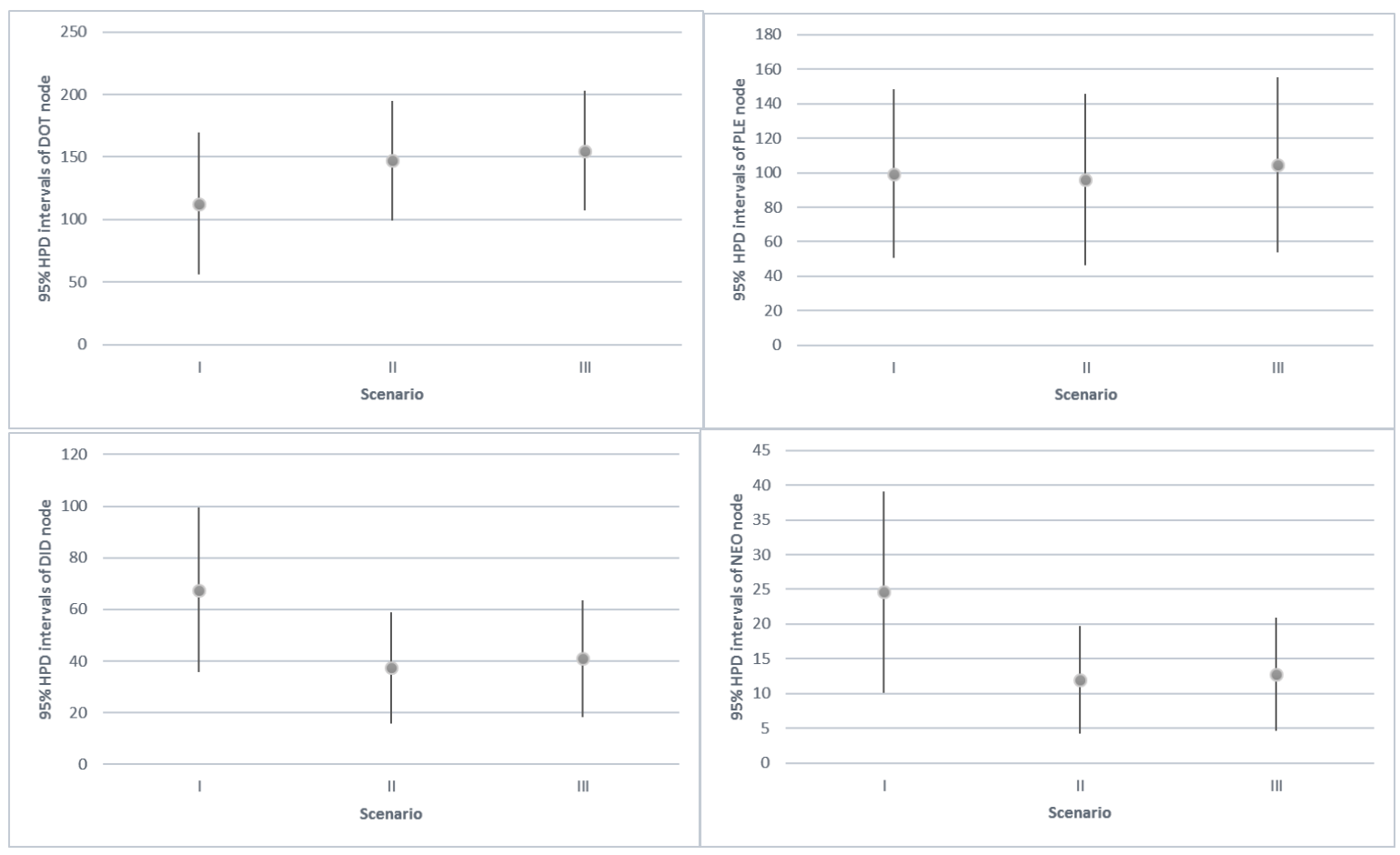

Figure 3 - Comparison means and interval of estimated age for MRCA of Dothideomycetes (DOT), Didymellaceae (DID), Pleosporales (PLE) and Neodidymelliopsis (NEO).

Table 3 The estimated divergence time of the crown nodes of Dothideomycetes in the three defined scenarios. Last column presents the estimated stem age in scenario III (the best scenario). Mean and 95\% HPD intervals of each node have been presented in square brackets in millions of years (Mya).

\begin{tabular}{lllll}
\hline Taxa (Node name) & $\begin{array}{l}\text { Scenario I } \\
\text { (1 Fossil) }\end{array}$ & $\begin{array}{l}\text { Scenario II } \\
\text { (2 Fossils) }\end{array}$ & \multicolumn{2}{l}{$\begin{array}{l}\text { Scenario III } \\
\text { (2 Fossils and 2 }\end{array}$} \\
\cline { 2 - 5 } & Crown node & Crown node & Crown node & Stem node \\
\hline Capnodiales (CAP) & $44.4[17.6-82.5]$ & $99[99-100.1]$ & $99[99-100.1]$ & $144.5[107-202.9]$ \\
Pleosporales (PLE) & $92.4[50.5-148.1]$ & $80.2[46.3-145.7]$ & $86.7[53.9-155.4]$ & $144.5[107-202.9]$ \\
Aigialus (AIG) & $34.1[34-38]$ & $34.1[34-59.4]$ & $34.1[34-64.4]$ & $86.7[53.9-155.4]$ \\
Didymellaceae (DID) & $63[35.6-99.4]$ & $32.5[16-59]$ & $35.7[18.4-63.5]$ & $86.7[53.9-155.4]$ \\
Neodidymelliopsis (NEO) & $21.9[10.1-39.1]$ & $10.1[4.3-19.7]$ & $10.9[4.7-20.87]$ & $27.3[15.9-45.8]$ \\
Iranian Neodidymelliopsis (IRneo) & $3.3[1.2-6.3]$ & $1.5[0.4-3.3]$ & $1.6[0.5-3.5]$ & $3.1[0.9-6.9]$ \\
\hline
\end{tabular}


Table 3 Continued.

\begin{tabular}{|c|c|c|c|c|}
\hline \multirow[t]{2}{*}{ Taxa (Node name) } & \multirow{2}{*}{$\begin{array}{l}\text { Scenario I } \\
\text { (1 Fossil) } \\
\text { Crown node } \\
\end{array}$} & \multirow{2}{*}{$\begin{array}{l}\text { Scenario II } \\
\text { (2 Fossils) } \\
\text { Crown node } \\
\end{array}$} & \multicolumn{2}{|c|}{$\begin{array}{l}\text { Scenario III } \\
\left(2 \text { Fossils and } 2^{\text {nd }} \text { calibration }\right)\end{array}$} \\
\hline & & & Crown node & Stem node \\
\hline Allophoma (ALL) & $14.2[7.2-23.3]$ & $7.4[3.6-13.5]$ & $7.7[3.8-13.8]$ & $10.8[5.8-18.7]$ \\
\hline Heterophoma (HET) & $15.1[7.5-24.6]$ & $7.7[3.6-13.9]$ & $8.02[3.8-14.3]$ & $10.8[5.8-18.7]$ \\
\hline Stagonosporopsis (STA) & $15.1[7-25.6]$ & $8[3-15]$ & $8.3[3.4-15.6]$ & $12.6[6.2-22]$ \\
\hline Boeremia $(\mathrm{BOE})$ & $9.1[3.9-16.5]$ & $4.3[1.4-8.9]$ & $4.5[1.6-9.3]$ & $13.8[7.5-24]$ \\
\hline Ectophoma (ECT) & $8.3[2.9-16.9]$ & $3.9[0.9-9.6]$ & $4.1[1-9.9]$ & $15.3[8.5-27]$ \\
\hline Remotididymella (REM) & $16.1[7.5-27.8]$ & $8.7[3.1-17.3]$ & $9.1[3.3-17.8]$ & $16.5[9.3-29.2]$ \\
\hline Epicoccum (EPI) & $15.6[7.6-26.3]$ & $8.3[3.7-15.6]$ & $8.6[4-16.2]$ & $15.4[7.9-27.5]$ \\
\hline Similiphoma (SIM) & $26.7[14.6-42.8]$ & $15[7.6-26.9]$ & $15.4[7.9-27.5]$ & $16.5[9.3-29.2]$ \\
\hline Didymella (DIM) & $21.4[10.9-35.4]$ & $12.6[5.8-23.2]$ & $13.1[6.05-23.8]$ & $17.1[9.3-29.6]$ \\
\hline Cumuliphoma (CUM) & $7.6[3.2-13.9]$ & $3.6[1.2-7.6]$ & $3.7[1.3-8]$ & $14.9[7.5-26.2]$ \\
\hline Paraboeremia (PAR) & $11.5[4.9-21.3]$ & $5.6[1.9-11.7]$ & $5.8[2.1-12.1]$ & $14.9[7.5-26.2]$ \\
\hline Macroventuria (MAC) & $5.4[1.5-11.6]$ & $2.7[0.5-7.5]$ & $2.9[0.5-7.8]$ & $16.9[8.6-26.2]$ \\
\hline Juxtiphoma (JUX) & $2.4[0.6-5.3]$ & $1.1[0.2-3.1]$ & $1.1[0.2-3.3]$ & $19[10.6-32.4]$ \\
\hline Vacuiphoma (VAC) & $16.6[6.2-31.1]$ & $9.3[2.5-19.6]$ & $9.9[2.7-20.4]$ & $21.6[12.7-35.3]$ \\
\hline Nothophoma (NOT) & $21.5[9.9-38.5]$ & $10.2[4.2-19.3]$ & $10.7[4.4-20]$ & $17.1[9.3-29.6]$ \\
\hline Ascochyta (ASC) & $14.7[6.9-25.3]$ & $7.5[3.1-13.8]$ & $8[3.5-14.5]$ & $11[5.7-19.2]$ \\
\hline Phomatodes (PHT) & $7.7[2.7-14.9]$ & $3.7[1-8.2]$ & $3.9[1.1-8.6]$ & $11[5.7-19.2]$ \\
\hline Phoma (PHO) & $1.2[0.3-2.8]$ & $0.6[0.1-1.6]$ & $0.6[0.1-1.7]$ & $16.5[9-27.7]$ \\
\hline Calophoma (CAL) & $23.1[11.5-38.1]$ & $12.3[5.6-21.8]$ & $13.1[6.3-23.1]$ & $18.5[10.2-30.7]$ \\
\hline Briansuttonomyces (BRI) & $0.1[0-0.9]$ & $0.1[0-0.7]$ & $0.1[0-0.7]$ & $6.3[2-13.2]$ \\
\hline Pseudoascochyta (PSE) & $3.2[1-6.6]$ & $1.5[0.3-3.9]$ & $1.6[0.3-4.1]$ & $6.3[2-13.2]$ \\
\hline Leptosphaerulina (LEP) & $14.3[5-27.6]$ & $6.7[1.7-14.8]$ & $7.2[2-15.9]$ & $20.2[11.7-33.7]$ \\
\hline Neomicrosphaeropsis (NEM) & $0.6[0.04-2]$ & $0.3[0.01-1.1]$ & $0.3[0.01-1.1]$ & $13.3[6.9-22.5]$ \\
\hline Xenodidymella (XEN) & $30.3[15.2-50.7]$ & $14.7[6.7-27.4]$ & $16[7.4-29.1]$ & $25.8[15-42.7]$ \\
\hline Neoascochyta (NEA) & $31.2[13.8-54.6]$ & $13.5[4-43.3]$ & $15.2[5.3-31.7]$ & $35.7[18.4-63.5]$ \\
\hline
\end{tabular}

\section{Discussion}

In recent decade, there has been an increasing interest in molecular dating of species as an effective way of studying molecular evolution (Ho \& Philips 2009, dos Reis et al. 2015). A few molecular dating studies have tried to estimate the divergence time of Ascomycetes and their orders (e.g. Beimforde et al. 2014, Hongsanan et al. 2016, Zhao et al. 2016, Hyde et al. 2017, Liu et al. 2017). In this study, we focused on divergence time of Didymellaceae genera for the first time, with added three Neodidymelliopsis and one Didymella isolates, collected from three provinces of Iran.

The phylogenetic tree indicated that Iranian Didymella isolate clustered with D. glomerata with a high bootstrap support, this result is also supported by morphological identification (data not published). Newly isolates of Neodidymelliopsis obtained in this study are closely related to $N$. longicolla with high bootstrap support. Morphological features of these new fungal isolates collected from citrus in southern Iran, confirmed that they share Neodidymelliopsis properties by having possessed pycnidial conidiomata and phialidic conidiogenesis, with hyaline, ampulliform, thin-walled conidiogenous cells, non or 1-septate, smooth-walled, hyaline to pale brown conidia. Characterization of conidiomata, conidia and conidiogenous cells of the isolates were in consistent with the description of Neodidymelliopsis reported by Chen et al. (2015). Since the main aim of this study was to focus on the molecular dating of these isolates, more morphological and pathological studies could be subject of further future works.

In the reconstructed phylogenetic tree (Fig. 1), the taxa related to Didymellaceae formed a sister group to the four selected Aigialus species within Pleosporales. The Capnodiales can be considered as an out-group, as they diverged from other taxa of Pleosporales. All the nodes of Didymellaceae, Aigialaceae, Pleosporales, and Capnodiales, where the main clusters have been 


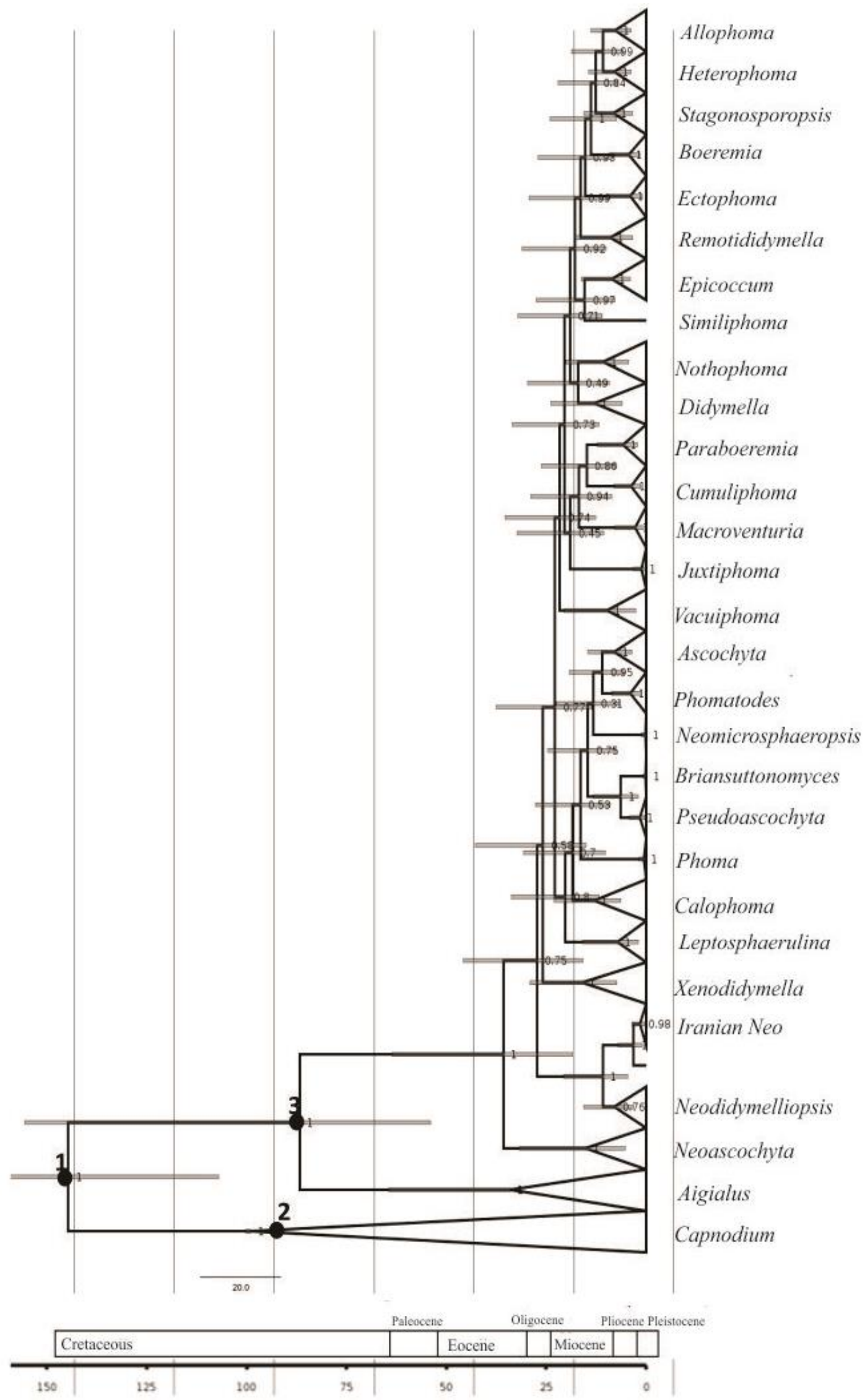

Figure 4 - Dated phylogenetic tree of scenario III. The numbers next to the nodes indicate the posterior probability values. The gray horizontal bars show the 95\% HPD intervals of the node ages. Nodes 1-3 are the calibration points (MRCA of Dothideomycetes, Capnodiales and Aigialus respectively). 
branched are well-supported (Fig. 1). These results are congruence with the previous studies (Aveskamp et al. 2010, Hyde et al. 2016, Phukhamsakda et al. 2016, Chen et al. 2017, ValenzuelaLopez et al. 2018). In molecular dating analyses, the means of estimated ages in scenario I (with one fossil) are lower than other scenarios, with widest interval of 95\% HPD (Supplementary table 3). Although the intervals of 95\% HPD and the estimated age of the nodes in scenario II and III are very similar, we consider scenario III as the best scenario due to the higher marginal likelihood.

Base on strains and parameters used in this study, we conclude that the earliest divergence in Didymellaceae is in the late Eocene when Neoascochyta diverged from other genera in Didymellaceae, this followed by the separation of Neodidymelliopsis and Xenodidymella in the late Oligocene. Other 23 genera diverged from others repeatedly in the Miocene. We speculate that geological changes such as mountain uplift, climate changes and aridification in the Miocene which led to an expansion of plants, might have resulted in the emergence of plant associated fungi as in Didymellaceae genera (Aveskamp et al. 2008, Chen et al. 2015). Iranian Neodidymelliopsis sp. and Didymella sp. isolates diverged from other isolates in the Pliocene and the late Miocene, respectively (Supplementary table 5), before switching to more seasonal, drier and cooler climate (Amo De Paz et al. 2011).

Moreover, the crown ages of five genera of Didymellaceae including Iranian Neodidymelliopsis sp. are in the Pleistocene. This result suggests that the glaciation event of Pleistocene is not restrictive for these genera, as already proposed for some Melanohalea species (Ascomycetes) by Leavitt et al. (2012). Five genera including Ascochyta, Neoascochyta, Heterophoma, Phomatodes and Neomicrosphaeropsis are specific to Fabaceae (Rosids), Poaceae (Monocots), Scrophulariaceae (Asterids), Brassicaceae (Rosids) and Tamaricaceae (Asterids), respectively. Among these five genera, Neoascochyta is the oldest genus which is hosted by Monocots which are older than Asterids and Rosids (Barba-Montoya et al. 2018). The estimated ages of Ascochyta and Phomatodes chronologically corresponds to the age of their hosts viz. Fabaceae and Brassicaceae, estimated by Hohmann et al. (2015). This coincidence supports the coevolution of Didymellaceae and their host plants proposed by Chen et al. (2017).

Furthermore, we compared the crown ages of Aigialus, Capnodiales and Didymellaceae with previous studies (Supplementary table 3). In agreement with Phukhamsakda et al. (2016), we dated Aigialus and Capnodiales to Eocene and Cretaceous, respectively. Similar to Prieto \& Wedin (2013) study, we dated the Dothideomycetes crown group to the late Jurassic or early Cretaceous. The variation in the ages of the taxa in previous studies could be the consequence of using different fossils, models, sampling and characters. Additionally, previous studies have mostly used a controversial fossil of Paleopyrenomycetes to calibrate nodes of the tree (Prieto \& Wedin 2013, Beimforde et al. 2014). Higher estimated ages in other studies can also be the result of considering exponential or normal distribution as the prior distribution for secondary calibration on the root note. In contrary, we prefer to use a uniform distribution, which based on Schenk (2016) simulation research. Further molecular dating studies in different locations and on various fungal taxa are needed to clarify this.

\section{Acknowledgements}

Partial financial support for this work by a research grant (No. 32-996) from the Research Council of Bu-Ali Sina University, Hamedan, Iran, is gratefully acknowledged.

\section{References}

Amo de Paz G, Cubas P, Divakar PK, Lumbsch HT, Crespo A. 2011 - Origin and Diversification of Major Clades in Parmelioid Lichens (Parmeliaceae, Ascomycota) during the Paleogene Inferred by Bayesian Analysis. PLoS One.

Aveskamp MM, de Gruyter J, Woudenberg JHC, Verkley G, Crous PW. 2010 - Highlights of the Didymellaceae: a polyphasic approach to characterise Phoma and related pleosporalean genera. Studies in Mycology 65, 1-60. 
Aveskamp MM, de Gruyter J, Crous PW. 2008 - Biology and recent developments in the systematics of Phoma: a complex genus of major quarantine significance. Fungal Diversity $31,1-18$.

Barba-Montoya J, dos Reis M, Schneider H, Donoghue PCJ, Yang Z. 2018 - Constraining uncertainty in the timescale of angiosperm evolution and the veracity of a Cretaceous Terrestrial Revolution. New Phytologist 218, 819-834.

Beimforde C, Feldberg K, Nylinder S, Rikkinen J et al. 2014 - Estimating the Phanerozoic history of the Ascomycota lineages: combining fossil and molecular data. Molecular Phylogenetics and Evolution 78, 386-398.

Berbee M, Taylor JW. 2010 - Dating the molecular clock in fungi-how close are we? Fungal Biology Reviews 24, 1-16.

Boehm EW, Mugambi GK, Miller AN, Huhndorf SM et al. 2009 - A molecular phylogenetic reappraisal of the Hysteriaceae, Mytilinidiaceae and Gloniaceae (Pleosporomycetidae, Dothideomycetes) with keys to world species. Studies in Mycology 64, 49-83.

Chen Q, Hou LW, Duan WJ, Crous PW, Cai L. 2017 - Didymellaceae revised. Studies in Mycology 87, 105-156.

Chen Q, Jiang JR, Zhang GZ, Cai L, Crous PW. 2015 - Resolving of Phoma enigma. Studies in Mycology 82, 137-217.

Chomnunti P, Hongsanan S, Hudson BA, Tian Q et al. 2014 - The sooty moulds. Fungal Diversity $66,1-36$.

Crous PW, Gams W, Stalpers JA, Vincent R. et al. 2004 - MycoBank: an online initiative to launch mycology into the $21^{\text {st }}$ century. Studies in Mycology 50, 19-22.

Crous PW, Groenewald JZ. 2017 - The Genera of Fungi - G 4: Camarosporium and Dothiora. IMA Fungus 8, 131-152.

Dai DQ, Boonmee S, Tian Q, Xiao YP et al. 2014 - Englerulaceae (Dothideomycetes). Phytotaxa 176(1), 139-155.

de Gruyter J, Aveskamp MM, Woudenberg JHC, Verkley GJM et al. 2009 - Molecular phylogeny of Phoma and allied anamorph genera: Towards a reclassification of the Phoma complex. Mycological Research 113, 508-519.

de Hoog GS, Gerrits van den EAHG. 1998 - Molecular diagnostics of clinical strains of filamentous Basidiomycetes. Mycoses 41, 183-189.

dos Reis M, Donoghue PCJ, Yang Z. 2015 - Bayesian molecular clock dating of species divergences in the genomics era. Nature Reviews Genetics 17, 71-80.

Doyle JJ, Doyle JL. 1987 - A rapid DNA isolation procedure for small quantities of fresh leaf tissue. Phytochemical Bulletin 19, 11-15.

Drummond AJ, Bouckaert RR. 2014 - Bayesian evolutionary analysis with BEAST 2. Cambridge University Press.

Drummond AJ, Suchard MA, Xie D, Rambaut A. 2012 - Bayesian Phylogenetics with BEAUti and the BEAST 1.7. Molecular Biology and Evolution 29 (8), 1969-73.

Ferreira MAR, Suchard MA. 2008 - Bayesian analysis of elapsed times in continuous-time Markov chains. Canadian Journal of Statistics 36 (3), 355-368.

Gueidan C, Ruibal C, de Hoog S, Schneider H. 2011 - Rock-inhabiting Fungi originated during periods of dry climate in the late Devonian and middle Triassic. Fungal Biology 115, 987996.

Hashimoto A, Matsumura M, Hirayama K, Fujimoto R et al. 2017 - Pseudodidymellaceae fam. nov.: phylogenetic affiliations of mycopappus-like genera in Dothideomycetes. Studies in Mycology 87, 187-206.

Ho SYW, Duchene S. 2014 - Molecular-clock methods for estimating evolutionary rates and timescales. Molecular Ecology 23 (24), 5947-5965.

Ho SYW, Philips MJ. 2009 - Accounting for calibration uncertainty in phylogenetics estimation of evolutionary divergence time. Systematic Biology 58(3), 367-380. 
Hohmann N, Wolf EM, Lysak MA, Kocha MA. 2015 - A Time-Calibrated Road Map of Brassicaceae Species Radiation and Evolutionary History. The Plant Cell 27, 2770-2784.

Hongsanan S, Sánchez-Ramírez S, Crous PW, Ariyawansa HA et al. 2016 - The evolution of fungal epiphytes. Mycosphere 7, 1690-1712.

Hyde KD, Hongsanan S, Jeewon R, Bhat DJ et al. 2016 - Fungal diversity notes 367-490: taxonomic and phylogenetic contributions to fungal taxa. Fungal Diversity 80, 1-270.

Hyde KD, Maharachchikumbura SSN, Hongsanan S, Samarakoon MC et al. 2017 - The ranking of fungi-a tribute to David L. Hawksworth on his 70th birthday. Fungal Diversity 84, 1-23.

Hyde KD, Nilsson RH, Alias SA, Ariyawansa HA et al. 2014 - One stop shop: backbones trees for important phytopathogenic genera: I. Fungal Diversity 67, 21-125.

Jia F, Lo N, Ho YW. 2014 - The impact of modelling rate heterogeneity among sites on phylogenetic estimates of intraspecific evolutionary rates and timescales. Plos One 9(5), e95722.

Katoh K, Standley DM. 2013 - MAFFT multiple sequence alignment software version 7: Improvements in performance and usability. Molecular Biology and Evolution 30, 772-780.

Kirk PM, Cannon PF, Minter DW, Stalpers JA. 2008 - Dictionary of the Fungi. Tenth Edition CSIRO.

Leavitt SD, Esslinger TL, Divakar PK Lumbsch HT. 2012 - Miocene and Pliocene dominated diversification of the lichen-forming fungal genus Melanohalea (Parmeliaceae, Ascomycota) and Pleistocene population expansions. Evolutionary Biology 12, 176.

Liu JK, Hyde KD, Jeewon R, Phillips AJL et al. 2017 - Ranking higher taxa using divergence times: a case study in Dothideomycetes. Fungal Diversity 84, 75-99.

Liu YJ, Whelen S, Hall BD. 1999 - Phylogenetic relationships among ascomycetes: evidence from an RNA polymerase II subunit. Molecular Biology and Evolution 16, 1799-1808.

Maddison WP, Maddison DR. 2015 - Mesquite: a modular system for evolutionary analysis. Version 3.04.

Mindell RA, Stockey RA, Beard G, Currah RS. 2007 - Margaretbarromyces dictyosporus gen. sp. nov.: a permineralized corticolous ascomycete from the Eocene of Vancouver Island, British Columbia. Mycological Research 111, 680-684.

Moran RJ, Morgan CC, O'Connell MJ. - 2015 A guide to phylogenetic reconstruction using heterogeneous models - a case study from the root of the placental mammal tree. Computation, 3, 77-196.

Nguyen LT, Schmidt HA, von Haeseler A, Minh BQ. 2014 - IQ-TREE: A fast and effective stochastic algorithm for estimating maximum-likelihood phylogenies. Molecular Biology and Evolution 32 (1), 268-274.

Pérez-Ortega S, Garrido-Benavent I, Grube M, Olmo R, de los Ríos A. 2016 - Hidden diversity of marine borderline lichens and a new order of fungi: Collemopsidiales (Dothideomyceta). Fungal Diversity 80, 285-300.

Phukhamsakda C, Hongsanan S, Ryberg M, Ariyawansa HA et al. 2016 - The evolution of Massarineae with Longipedicellataceae fam. nov. Mycosphere 7 (11), 1713-1731.

Prieto M, Wedin M. 2013 - Dating the diversification of the major lineages of Ascomycota (Fungi). PLoS One 14, e65576.

Rehner SA, Samuels GJ. 1994 - Taxonomy and phylogeny of Gliocladium analysed from nuclear large subunit ribosomal DNA sequences. Mycological Research 98, 625-634.

Rutschmann F. 2006 - Molecular Dating of phylogenetic trees: a brief review of current methods that estimate divergence times. Diversity and Distributions 12 (1), 35-48.

Schenk JJ. 2016 - Consequences of Secondary Calibrations on Divergence Time Estimates. PLoS One 11(1), 1-17.

Schmidt AR, Beimforde C, Seyfullah LJ, Wege SE et al. 2014 - Amber fossils of sooty moulds. Review of Palaeobotany and Palynology 200, 53-64. 
Sung GH, Sung JM, Hywel-Jones NL, Spatafor JW. 2007 - A multi-gene phylogeny of Clavicipitaceae (Ascomycota, Fungi): identification of localized incongruence using a combinational bootstrap approach. Molecular Phylogenetics and Evolution 44. 1204-1223.

Taylor JE, Hyde KD. 2003 - Microfungi of tropical and temperate palms. Fungal Diversity Research 12, 1-459.

Vaidya G, Lohman D, Meier J. 2011 - SequenceMatrix: concatenation software for the fast assembly of multi-gene datasets with character set and codon information. Cladistics 27, 171-180.

Valenzuela-Lopez N, Cano-Lira JF, Guarro J, Sutton DA et al. 2018 - Coelomycetous Dothideomycetes with emphasis on the families Cucurbitariaceae and Didymellaceae. Studies in Mycology 90, 1-69.

Vijaykrishna D, Jeewon R, Hyde KD. 2006 - Molecular taxonomy, origins and evolution of freshwater ascomycetes. Fungal Diversity 23, 351-390.

Vilgalys R, Hester M. 1990 - Rapid genetic identification and mapping of enzymatically amplified ribosomal DNA from several Cryptococcus species. Journal of Bacteriology 17, 4238-4246.

White TJ, Bruns T, Lee S, Taylor J. 1990 - Amplification and direct sequencing of fungal ribosomal RNA genes for phylogenetics. PCR Protocols: A guide to Methods and Applications.

Wijayawardene NN, Hyde KD, Dhanushka NW, Papizadeh M et al. 2016 - Taxonomy and phylogeny of dematiaceous coelomycetes. Fungal Diversity 77, 1-310.

Wijayawardene NN, Hyde KD, Lumbsch HT, Liu JK et al. 2018 - Outline of Ascomycota: 2017. Fungal Diversity 88, 167-263.

Wijayawardene NN, Hyde KD, Rajeshkumar KC, Hawksworth DL et al. 2017 - Notes for genera Ascomycota. Fungal Diversity. 86, 1-594.

Woudenberg JHC, Aveskamp MM, de Gruyter J, Spiers AG, Crous PW. 2009 - Multiple Didymella teleomorphs are linked to the Phoma clematidina morphotype. Persoonia 22, 5662.

Zhao RL, Zhou JL, Chen J, Margaritescu S et al.2016 - Towards standardizing taxonomic ranks using divergence times-a case study for reconstruction of the Agaricus taxonomic system. Fungal Diversity 78, 239-292.

Zuckerkandl E, Pauling L. 1965 - Evolutionary divergence and convergence in proteins. Evolving Genes and Proteins 97-166.

\section{Supplementary Informations}

Supplementary table 1 Strains used in this study and their GeneBank accession numbers.

\begin{tabular}{|c|c|c|c|c|c|c|c|}
\hline \multirow{2}{*}{$\begin{array}{l}\text { Isolate } \\
\text { name }\end{array}$} & \multirow{2}{*}{$\begin{array}{l}\text { Strain } \\
\text { number }\end{array}$} & \multirow[t]{2}{*}{ Host } & \multirow[t]{2}{*}{ Province } & \multicolumn{4}{|c|}{ GeneBank Accession Number } \\
\hline & & & & LSU & TUB & RPB2 & ITS \\
\hline IR26 & $\begin{array}{l}\text { CBS } \\
142211 ; \\
\text { IRAN } \\
2770 \mathrm{C}\end{array}$ & $\begin{array}{l}\text { Citrus } \\
\text { paradisi }\end{array}$ & $\begin{array}{l}\text { Khuzesta } \\
\mathrm{n}\end{array}$ & $\begin{array}{l}\text { KY35507 } \\
4\end{array}$ & $\begin{array}{l}\text { KY40779 } \\
0\end{array}$ & KY386285 & KY290226 \\
\hline IR14 & $\begin{array}{l}\text { CBS } \\
142210\end{array}$ & $\begin{array}{l}\text { Citrus } \\
\text { aurantium }\end{array}$ & Kerman & $\begin{array}{l}\text { KY35507 } \\
3\end{array}$ & $\begin{array}{l}\text { KY40778 } \\
9\end{array}$ & KY386284 & KY290225 \\
\hline IR10 & $\begin{array}{l}\text { CBS } \\
142208 \\
\text { IRAN } \\
2771 C\end{array}$ & Citrus sinensis & Kerman & $\begin{array}{l}\text { KY35507 } \\
2\end{array}$ & $\begin{array}{l}\text { KY40778 } \\
8\end{array}$ & KY386283 & KY290224 \\
\hline IR67 & $\begin{array}{l}\text { CBS } \\
142212 \\
\text { IRAN } \\
2768 C\end{array}$ & Citrus lemon & $\begin{array}{l}\text { Hormozg } \\
\text { an }\end{array}$ & $\begin{array}{l}\text { KY35507 } \\
5\end{array}$ & $\begin{array}{l}\text { KY40779 } \\
1\end{array}$ & KY386286 & KY290228 \\
\hline
\end{tabular}


Supplementary table 2 GeneBank, culture collection code and accession numbers of the isolates used in this study.

\begin{tabular}{|c|c|c|c|c|c|c|c|}
\hline \multirow{2}{*}{ Species Name } & \multirow{2}{*}{$\begin{array}{l}\text { Strain } \\
\text { Number }{ }^{1}\end{array}$} & \multirow{2}{*}{$\begin{array}{l}\text { Host, } \\
\text { Substrate }\end{array}$} & \multirow{2}{*}{ Country } & \multicolumn{4}{|c|}{ GeneBank Accession Number } \\
\hline & & & & LSU & ITS & TUB & RPB2 \\
\hline Aigialus grandis & BCC 20000 & $\begin{array}{l}\text { Mangrove } \\
\text { wood }\end{array}$ & Malaysia & $\begin{array}{l}\text { GU4797 } \\
75\end{array}$ & - & - & $\begin{array}{l}\text { GU4798 } \\
14\end{array}$ \\
\hline A. mangrovei & BCC 33563 & $\begin{array}{l}\text { Mangrove } \\
\text { wood }\end{array}$ & Thailand & $\begin{array}{l}\text { GU4797 } \\
76\end{array}$ & - & - & $\begin{array}{l}\text { GU4798 } \\
15\end{array}$ \\
\hline A. parvus & BCC 18403 & $\begin{array}{l}\text { Mangrove } \\
\text { wood }\end{array}$ & Malaysia & $\begin{array}{l}\text { GU4797 } \\
78\end{array}$ & - & - & $\begin{array}{l}\text { GU4798 } \\
17\end{array}$ \\
\hline A. rhizophorae & BCC 33572 & $\begin{array}{l}\text { Mangrove } \\
\text { wood }\end{array}$ & Thailand & $\begin{array}{l}\text { GU4797 } \\
80\end{array}$ & - & - & $\begin{array}{l}\text { GU4798 } \\
19\end{array}$ \\
\hline $\begin{array}{l}\text { Allophoma } \\
\text { labilis }\end{array}$ & CBS 124.93 & $\begin{array}{l}\text { Solanum } \\
\text { lycopersicum }\end{array}$ & $\begin{array}{l}\text { The } \\
\text { Netherlands }\end{array}$ & $\begin{array}{l}\text { GU2380 } \\
91\end{array}$ & $\begin{array}{l}\text { GU2377 } \\
65\end{array}$ & $\begin{array}{l}\text { GU2376 } \\
19\end{array}$ & $\begin{array}{l}\text { KT3895 } \\
52\end{array}$ \\
\hline A. minor & $\begin{array}{l}\text { CBS 325.82; } \\
\text { FMR } 14905\end{array}$ & $\begin{array}{l}\text { Syzygium } \\
\text { aromaticum }\end{array}$ & Indonesia & $\begin{array}{l}\text { GU2381 } \\
07\end{array}$ & $\begin{array}{l}\text { GU2378 } \\
31\end{array}$ & $\begin{array}{l}\text { GU2376 } \\
32\end{array}$ & $\begin{array}{l}\text { KT3895 } \\
53\end{array}$ \\
\hline A. piperis & CBS 268.93 & $\begin{array}{l}\text { Peperomia } \\
\text { pereskiifolia }\end{array}$ & $\begin{array}{l}\text { The } \\
\text { Netherlands }\end{array}$ & $\begin{array}{l}\text { GU2381 } \\
29\end{array}$ & $\begin{array}{l}\text { GU2378 } \\
16\end{array}$ & $\begin{array}{l}\text { GU2376 } \\
44\end{array}$ & $\begin{array}{l}\text { KT3895 } \\
54\end{array}$ \\
\hline $\begin{array}{l}\text { A. } \\
\text { zantedeschiae }\end{array}$ & CBS 131.93 & Calla sp. & $\begin{array}{l}\text { The } \\
\text { Netherlands }\end{array}$ & $\begin{array}{l}\text { GU2381 } \\
59\end{array}$ & $\begin{array}{l}\text { FJ42708 } \\
4\end{array}$ & $\begin{array}{l}\text { FJ42718 } \\
8\end{array}$ & $\begin{array}{l}\text { KT3895 } \\
57\end{array}$ \\
\hline $\begin{array}{l}\text { Ascochyta } \\
\text { rabiei }\end{array}$ & CBS 206.30 & Unknown & Unknown & $\begin{array}{l}\text { KT3896 } \\
95\end{array}$ & $\begin{array}{l}\text { KT3894 } \\
78\end{array}$ & $\begin{array}{l}\text { KT3897 } \\
72\end{array}$ & $\begin{array}{l}\text { KT3895 } \\
59\end{array}$ \\
\hline A. versabilis & CBS 876.97 & Silene sp. & $\begin{array}{l}\text { The } \\
\text { Netherlands }\end{array}$ & $\begin{array}{l}\text { GU2381 } \\
52\end{array}$ & $\begin{array}{l}\text { GU2379 } \\
09\end{array}$ & $\begin{array}{l}\text { GU2376 } \\
64\end{array}$ & $\begin{array}{l}\text { KT3895 } \\
61\end{array}$ \\
\hline A. viciae & CBS 451.68 & Vicia sepium & $\begin{array}{l}\text { The } \\
\text { Netherlands }\end{array}$ & $\begin{array}{l}\text { KT3897 } \\
01\end{array}$ & $\begin{array}{l}\text { KT3894 } \\
84\end{array}$ & $\begin{array}{l}\text { KT3897 } \\
78\end{array}$ & $\begin{array}{l}\text { KT3895 } \\
62\end{array}$ \\
\hline $\begin{array}{l}\text { Boeremia } \\
\text { exigual }\end{array}$ & CBS 118.38 & $\begin{array}{l}\text { Cheiranthus } \\
\text { cheiri }\end{array}$ & Denmark & $\begin{array}{l}\text { KT3897 } \\
06\end{array}$ & $\begin{array}{l}\text { KT3894 } \\
89\end{array}$ & $\begin{array}{l}\text { KT3897 } \\
83\end{array}$ & $\begin{array}{l}\text { KT3895 } \\
82\end{array}$ \\
\hline B. exigua2 & CBS 119.38 & $\begin{array}{l}\text { Nicotiana } \\
\text { tabacum }\end{array}$ & Unknown & $\begin{array}{l}\text { KT3897 } \\
07\end{array}$ & $\begin{array}{l}\text { KT3894 } \\
90\end{array}$ & $\begin{array}{l}\text { KT3897 } \\
84\end{array}$ & $\begin{array}{l}\text { KT3895 } \\
83\end{array}$ \\
\hline B. lycopersici & CBS 378.67 & $\begin{array}{l}\text { Solanum } \\
\text { lycopersicum }\end{array}$ & $\begin{array}{l}\text { The } \\
\text { Netherlands }\end{array}$ & $\begin{array}{l}\text { GU2379 } \\
50\end{array}$ & $\begin{array}{l}\text { GU2378 } \\
48\end{array}$ & $\begin{array}{l}\text { GU2375 } \\
12\end{array}$ & $\begin{array}{l}\text { KT3895 } \\
80\end{array}$ \\
\hline $\begin{array}{l}\text { Briansuttonomy } \\
\text { ces eucalypti }\end{array}$ & $\begin{array}{l}\text { CBS } 114879 ; \\
\text { CPC } 362\end{array}$ & Eucalyptus sp. & South Africa & $\begin{array}{l}\text { KU7285 } \\
19\end{array}$ & $\begin{array}{l}\text { KU7284 } \\
79\end{array}$ & $\begin{array}{l}\text { KU7285 } \\
95\end{array}$ & - \\
\hline B. eucalypti & $\begin{array}{l}\text { CBS 11887; } \\
\text { CPC } 363\end{array}$ & Eucalyptus sp. & South Africa & $\begin{array}{l}\text { KU7285 } \\
20\end{array}$ & $\begin{array}{l}\text { KU7284 } \\
80\end{array}$ & $\begin{array}{l}\text { KU7285 } \\
96\end{array}$ & - \\
\hline $\begin{array}{l}\text { Calophoma. } \\
\text { aquilegiicola }\end{array}$ & CBS 107.96 & $\begin{array}{l}\text { Aconitum } \\
\text { pyramidale }\end{array}$ & $\begin{array}{l}\text { The } \\
\text { Netherlands }\end{array}$ & $\begin{array}{l}\text { GU2380 } \\
41\end{array}$ & $\begin{array}{l}\text { GU2377 } \\
35\end{array}$ & $\begin{array}{l}\text { GU2375 } \\
81\end{array}$ & $\begin{array}{l}\text { KT3895 } \\
86\end{array}$ \\
\hline C. clematidina & CBS 102.66 & Clematis sp. & UK & $\begin{array}{l}\text { FJ51563 } \\
0\end{array}$ & $\begin{array}{l}\text { FJ42698 } \\
8\end{array}$ & $\begin{array}{l}\text { FJ42709 } \\
9\end{array}$ & $\begin{array}{l}\text { KT3895 } \\
87\end{array}$ \\
\hline $\begin{array}{l}\text { C. clematidis- } \\
\text { rectae }\end{array}$ & CBS 507.63 & Clematis sp. & $\begin{array}{l}\text { The } \\
\text { Netherlands }\end{array}$ & $\begin{array}{l}\text { FJ51564 } \\
7\end{array}$ & $\begin{array}{l}\text { FJ51560 } \\
6\end{array}$ & $\begin{array}{l}\text { FJ51562 } \\
4\end{array}$ & $\begin{array}{l}\text { KT3895 } \\
89\end{array}$ \\
\hline C. rosae & $\begin{array}{l}\text { CGMCC } \\
3.18347\end{array}$ & Rosa sp. & China & $\begin{array}{l}\text { KY7422 } \\
03\end{array}$ & $\begin{array}{l}\text { KY7420 } \\
49\end{array}$ & $\begin{array}{l}\text { KY7422 } \\
91\end{array}$ & $\begin{array}{l}\text { KY7421 } \\
35\end{array}$ \\
\hline $\begin{array}{l}\text { Capnodiales } \\
\text { sp.001 }\end{array}$ & 010301 & $\begin{array}{l}\text { Dacrydium } \\
\text { araucarioides }\end{array}$ & $\begin{array}{l}\text { New } \\
\text { Caledonia }\end{array}$ & $\begin{array}{l}\text { KF1579 } \\
91\end{array}$ & - & - & - \\
\hline $\begin{array}{l}\text { Capnodiales } \\
\text { sp.003 }\end{array}$ & 010302 & $\begin{array}{l}\text { Epiphytic } \\
\text { fungus }\end{array}$ & $\begin{array}{l}\text { New } \\
\text { Caledonia }\end{array}$ & $\begin{array}{l}\text { KF1579 } \\
92\end{array}$ & - & - & - \\
\hline $\begin{array}{l}\text { Capnodium } \\
\text { coffeae }\end{array}$ & CBS 147.52 & & & $\begin{array}{l}\text { DQ2478 } \\
00\end{array}$ & - & - & $\begin{array}{l}\text { DQ2477 } \\
88\end{array}$ \\
\hline $\begin{array}{l}\text { Cumuliphoma } \\
\text { indical }\end{array}$ & $\begin{array}{l}\text { CBS 654.77; } \\
\text { FMR } 15341\end{array}$ & Unknown & India & $\begin{array}{l}\text { GU2381 } \\
22\end{array}$ & $\begin{array}{l}\text { FJ42704 } \\
3\end{array}$ & $\begin{array}{l}\text { FJ42715 } \\
3\end{array}$ & $\begin{array}{l}\text { LT6232 } \\
61\end{array}$ \\
\hline C.indica2 & $\begin{array}{l}\text { CBS 991.95; } \\
\text { FMR 15331 }\end{array}$ & Soil & $\begin{array}{l}\text { Papua New } \\
\text { Guinea }\end{array}$ & $\begin{array}{l}\text { GU2381 } \\
21\end{array}$ & $\begin{array}{l}\text { FJ42704 } \\
4\end{array}$ & $\begin{array}{l}\text { FJ42715 } \\
4\end{array}$ & $\begin{array}{l}\text { LT6232 } \\
62\end{array}$ \\
\hline
\end{tabular}


Supplementary table 2 Continued.

\begin{tabular}{|c|c|c|c|c|c|c|c|}
\hline \multirow{2}{*}{ Species Name } & \multirow{2}{*}{$\begin{array}{l}\text { Strain } \\
\text { Number }{ }^{1}\end{array}$} & \multirow{2}{*}{$\begin{array}{l}\text { Host, } \\
\text { Substrate }\end{array}$} & \multirow{2}{*}{ Country } & \multicolumn{4}{|c|}{ GeneBank Accession Number } \\
\hline & & & & LSU & ITS & TUB & RPB2 \\
\hline \multirow[t]{2}{*}{ C. omnivirens } & CBS 341.86; & Phaseolus & Belgium & LT6232 & FJ42704 & FJ42715 & LT6232 \\
\hline & FMR 14915 & vulgaris & & 14 & 2 & 2 & 60 \\
\hline \multirow[t]{3}{*}{ C. pneumoniae } & CBS 142454; & Human & USA & LN9073 & LT5929 & LT5929 & LT5930 \\
\hline & UTHSC: & respiratory & & 92 & 25 & 94 & 63 \\
\hline & $\begin{array}{l}\text { DL16-246; } \\
\text { FMR } 13739\end{array}$ & tract & & & & & \\
\hline \multirow[t]{2}{*}{ D. aliena } & CBS 379.93 & Berberis sp. & TheNetherla & GU2380 & GU2378 & GU2375 & KP3304 \\
\hline & & & & 37 & 51 & 78 & 16 \\
\hline \multirow[t]{2}{*}{ D. arachidicola } & CBS 333.75 & Arachis & South Africa & GU2379 & GU2378 & GU2375 & KT3895 \\
\hline & & hypogaea & & 96 & 33 & 54 & 98 \\
\hline \multirow[t]{2}{*}{ D. glomerata } & CBS 528.66; & Chrysanthemu & TheNetherla & JX6811 & FJ42701 & FJ42712 & GU3717 \\
\hline & PD 63/590 & $m \mathrm{sp}$ & & 05 & 3 & 4 & 81 \\
\hline \multirow{2}{*}{$\begin{array}{l}\text { Didymella } \\
\text { pinodes }\end{array}$} & CBS 525.77 & Pisum sativum & Belgium & GU2380 & GU2378 & GU2375 & KT3896 \\
\hline & & & & 23 & 83 & 72 & 14 \\
\hline \multirow{3}{*}{$\begin{array}{l}\text { Ectophoma } \\
\text { multirostratal } \\
\text { E. }\end{array}$} & CBS 110.79; & Cucumis & TheNetherla & GU2381 & FJ42703 & FJ42714 & LT6232 \\
\hline & FMR 15342 & sativus & nd & 10 & 0 & 0 & 64 \\
\hline & CBS 274.60; & Soil & Maharashtra & GU2381 & FJ42703 & FJ42714 & LT6232 \\
\hline \multirow{2}{*}{$\begin{array}{l}\text { multirostrata2 } \\
\text { E. }\end{array}$} & FMR 15335 & & & 11 & 1 & 1 & 65 \\
\hline & CBS 368.65; & Unknown & India & GU2381 & FJ42703 & FJ42714 & T62326 \\
\hline \multirow{3}{*}{$\begin{array}{l}\text { multirostrata } 3 \\
\text { E. pomi }\end{array}$} & FMR 15336 & & & 12 & 3 & $3 \mathrm{~L}$ & 6 \\
\hline & CBS 267.92; & Coffea arabica & India & GU2381 & GU2378 & GU2376 & LT6232 \\
\hline & FMR 15346 & & & 28 & 14 & 43 & 63 \\
\hline \multirow{4}{*}{$\begin{array}{l}\text { Epicoccum } \\
\text { brasiliense } \\
\text { E. draconis }\end{array}$} & CBS 120105; & Amaranthus & Brazil & GU2380 & GU2377 & GU2375 & KT3896 \\
\hline & FMR 14907 & sp. & & 49 & 60 & 88 & 27 \\
\hline & CBS 186.83; & Dracaena sp. & Rwanda & GU2380 & GU2377 & GU2376 & KT3896 \\
\hline & FMR14908 & & & 70 & 95 & 07 & 28 \\
\hline \multirow[t]{2}{*}{ E. henningsii } & CBS 104.80 & Acaciamearnsi & Kenya & GU2380 & GU2377 & GU2376 & KT3896 \\
\hline & & & & 81 & 31 & 12 & 29 \\
\hline \multirow[t]{2}{*}{ E. plurivorum } & CBS 558.81; & Setaria sp. & New Zealand & GU2381 & GU2378 & GU2376 & KT3896 \\
\hline & FMR 14909 & & & 32 & 88 & 47 & 34 \\
\hline \multirow{4}{*}{$\begin{array}{l}\text { Heterophoma } \\
\text { adonidis } \\
\text { H. nobilis }\end{array}$} & CBS 114309 & Adonis & Sweden & KT3897 & KT3895 & KT3898 & KT3896 \\
\hline & & vernalis & & 24 & 06 & 03 & 37 \\
\hline & CBS 507.91 & Dictamnus & The & GU2380 & GU2378 & GU2376 & KT3896 \\
\hline & & albus & Netherlands & 65 & 77 & 03 & 38 \\
\hline \multirow{4}{*}{$\begin{array}{l}H . \\
\text { verbascicola1 } \\
H . \\
\text { verbascicola2 }\end{array}$} & CGMCC & Verbascum & China & KY7422 & KY7421 & KY7423 & KY7421 \\
\hline & 3.18364 & thapsus & & 73 & 19 & 61 & 87 \\
\hline & LC 8164 & Verbascum & China & KY7422 & KY7421 & KY7423 & KY7421 \\
\hline & & thapsus & & 74 & 20 & 62 & 88 \\
\hline Juxtiphoma & CBS 374.91; & Solanum & The & GU2380 & FJ42699 & FJ42711 & LT6232 \\
\hline eupyrenal & FMR 15329 & tuberosum & Netherlands & 72 & 9 & 0 & 68 \\
\hline J. eupyrena2 & CBS 527.66; & Wheat field & Germany & GU2380 & FJ42700 & FJ42711 & LT6232 \\
\hline & FMR 15337 & soil & & 73 & 0 & 1 & 69 \\
\hline Leptosphaerulin & CBS 213.55 & Trifolium & USA & GU2379 & GU2377 & GU2375 & KT3896 \\
\hline & & & & 81 & 99 & 39 & 41 \\
\hline L. australis & CBS 317.83 & Eugenia & Indonesia & EU7541 & GU2378 & GU2375 & GU3717 \\
\hline & & & & 66 & 29 & 40 & 90 \\
\hline Macroventuria & CBS 525.71 & Decayed & South Africa & GU2379 & GU2378 & GU2375 & GU4563 \\
\hline & & & & 84 & 81 & 44 & 46 \\
\hline M. wentii & CBS 526.71 & Plant litter & USA & GU2379 & GU2378 & GU2375 & KT3896 \\
\hline & & & & 86 & 84 & 46 & 42 \\
\hline Neoascochyta & CBS 297.69 & Lolium & Germany & KT3897 & KT3895 & KT3898 & KT3896 \\
\hline desmazieri & & perenne & & 26 & 08 & 07 & \\
\hline
\end{tabular}


Supplementary table 2 Continued.

\begin{tabular}{|c|c|c|c|c|c|c|c|}
\hline \multirow{2}{*}{ Species Name } & \multirow{2}{*}{$\begin{array}{l}\text { Strain } \\
\text { Number }^{1}\end{array}$} & \multirow{2}{*}{$\begin{array}{l}\text { Host, } \\
\text { Substrate }\end{array}$} & \multirow{2}{*}{ Country } & \multicolumn{4}{|c|}{ GeneBank Accession Number } \\
\hline & & & & LSU & ITS & TUB & RPB2 \\
\hline \multirow[t]{2}{*}{ N. europaea } & CBS 820.84 & Hordeum & Germany & KT3897 & KT3895 & KT3898 & KT3896 \\
\hline & & vulgare & & 29 & 11 & 09 & 46 \\
\hline \multirow[t]{2}{*}{ N. exitialis } & CBS 118.40 & Unknown & Unknown & KT3897 & KT3895 & KT3898 & KT3896 \\
\hline & & & & 32 & 14 & 12 & 47 \\
\hline \multirow[t]{2}{*}{ N. graminicola } & CBS 301.69 & Lolium & Germany & KT3897 & KT3895 & KT3898 & KT3896 \\
\hline & & multiflorum & & 37 & 19 & 17 & 50 \\
\hline \multirow{2}{*}{$\begin{array}{l}\text { Neodidymelliop } \\
\text { sis cannabis }\end{array}$} & CBS 234.37 & Cannabis & Unknown & GU2379 & GU2378 & GU2375 & KP3304 \\
\hline & & sativa & & 61 & 04 & 23 & 03 \\
\hline \multirow[t]{2}{*}{ N. longicolla } & CBS 38296 & Soil in desert & Israel & KT3897 & KT3895 & KT3898 & - \\
\hline & & & & 50 & 32 & 30 & \\
\hline \multirow[t]{2}{*}{$N$. polemonii } & CBS 109181 & Polemonium & TheNetherla & GU2381 & GU2377 & KT3898 & KP3304 \\
\hline & & caeruleum & & 33 & 46 & 28 & 27 \\
\hline \multirow[t]{2}{*}{ N. xanthina } & CBS 383.68 & Delphinium sp. & TheNetherla & GU2381 & GU2378 & KT3898 & KP3304 \\
\hline & & & nds & 57 & 55 & 31 & 31 \\
\hline \multirow{4}{*}{$\begin{array}{l}\text { Neomicrosphaer } \\
\text { iopsis italica } \\
\text { N. italica }\end{array}$} & MFLUCC 15- & Tamarix sp. & Italy & KU7298 & KU9003 & - & KU6748 \\
\hline & 0485 & & & 54 & 18 & & 20 \\
\hline & MFLUCC 15- & Tamarix sp. & Italy & KU7298 & KU9003 & KX4532 & KU6955 \\
\hline & 0484 & & & 53 & 19 & 98 & 39 \\
\hline \multirow{4}{*}{$\begin{array}{l}\text { Nothophoma } \\
\text { anigozanthi } \\
\text { N. arachidis- } \\
\text { hypogaeae }\end{array}$} & CBS 381.91; & Anigozanthus & The & GU2380 & GU2378 & GU2375 & KT3896 \\
\hline & FMR 14914 & maugleisii & Netherlands & 39 & 52 & 80 & 55 \\
\hline & CBS 125.93 & Arachis & India & GU2380 & GU2377 & GU2375 & KT3896 \\
\hline & & hypogaea & & 43 & 71 & 83 & 56 \\
\hline \multirow[t]{2}{*}{ N. gossypiicola } & CBS 377.67; & Gossypium sp. & USA & GU2380 & GU2378 & GU2376 & KT3896 \\
\hline & FMR14912 & & & 79 & 45 & 11 & 58 \\
\hline \multirow[t]{2}{*}{ N. infossa } & CBS 123395 & Fraxinus & Argentina & GU2380 & FJ42702 & FJ42713 & KT3896 \\
\hline & & pennsylvanica & & 89 & 5 & 5 & 59 \\
\hline \multirow{4}{*}{$\begin{array}{l}\text { Paraboeremia } \\
\text { adianticola } \\
\text { P. litseae }\end{array}$} & CBS 187.83; & Polystichum & USA & GU2380 & GU2377 & GU2375 & KP3304 \\
\hline & FMR 15344 & adiantiforme & & 35 & 96 & 76 & 01 \\
\hline & CGMCC & Litsea sp. & China & KX8290 & KX8290 & KX8290 & KX8290 \\
\hline & 3.18110 & & & 37 & 29 & 53 & 45 \\
\hline \multirow[t]{2}{*}{ P. putaminum } & CBS 130.69; & Malus & Denmark & GU2381 & GU2377 & GU2376 & LT6232 \\
\hline & FMR 15338 & sylvestris & & 38 & 77 & 52 & 54 \\
\hline \multirow[t]{2}{*}{ P. selaginellae } & CBS122.93 & Selaginella sp. & The & GU2381 & GU2377 & GU2376 & LT6232 \\
\hline & & & Netherlands & 42 & 62 & 56 & 55 \\
\hline & CBS 377.92; & Human leg & UK & KT3897 & KT3895 & KT3898 & KT3896 \\
\hline herbaruml & IMI 21384 & & & 56 & 36 & 37 & 63 \\
\hline P. herbarum 2 & UTHSC:DL16 & Humansuperfic & USA & LN9074 & LT5929 & LT5930 & LT5930 \\
\hline & $\begin{array}{l}-319 ; \\
\text { FMR } 13812\end{array}$ & ial tissue & & 62 & 55 & 24 & 24 \\
\hline P. herbarum3 & CBS 502.91 & Nerium sp. & The & GU2380 & GU2378 & GU2376 & KP3304 \\
\hline & & & Netherlands & 82 & 74 & 13 & 19 \\
\hline P. herbarum4 & CBS 615.75; & Rosa multiflora & The & KF2517 & FJ42702 & KF2527 & KP3304 \\
\hline & & $\begin{array}{l}\text { cv. } \\
\text { Cathayensis }\end{array}$ & Netherlands & 15 & 2 & 03 & 20 \\
\hline Phomatodes & CBS 627.97 & Aubrietia sp. & The & GU2380 & GU2378 & GU2375 & KT3896 \\
\hline aubrietiae & & & Netherlands & 45 & 95 & 85 & 65 \\
\hline P. nebulosi & CBS 100191 & Thlaspi & Poland & KP3304 & KP3304 & KP3303 & KT3896 \\
\hline & & & & 46 & 34 & 90 & \\
\hline P. nebulosi & CBS 740.96 & Armoracia & The & KT3897 & KT3895 & KT3898 & KT3896 \\
\hline & & & & 58 & 40 & 39 & 67 \\
\hline Pseudoascochyt & CBS 141689; & Cordyline & New Zealand & LT5928 & LT5928 & LT5928 & LT5928 \\
\hline $\begin{array}{l}\text { a novae- } \\
\text { zelandiea }\end{array}$ & $\begin{array}{l}\text { FMR 15110; } \\
\text { ICMP } 10493\end{array}$ & australis & & 93 & 92 & 94 & 95 \\
\hline
\end{tabular}


Supplementary table 2 Continued.

\begin{tabular}{|c|c|c|c|c|c|c|c|}
\hline \multirow{2}{*}{ Species Name } & \multirow{2}{*}{$\begin{array}{l}\text { Strain } \\
\text { Number }^{1}\end{array}$} & \multirow{2}{*}{$\begin{array}{l}\text { Host, } \\
\text { Substrate }\end{array}$} & \multirow{2}{*}{ Country } & \multicolumn{4}{|c|}{ GeneBank Accession Number } \\
\hline & & & & LSU & ITS & TUB & RPB2 \\
\hline$P$. pratensis & $\begin{array}{l}\text { CBS 141688; } \\
\text { FMR 14524 }\end{array}$ & Soil & Spain & $\begin{array}{l}\text { LT2231 } \\
31\end{array}$ & $\begin{array}{l}\text { LT2231 } \\
30\end{array}$ & $\begin{array}{l}\text { LT2231 } \\
32\end{array}$ & $\begin{array}{l}\text { LT2231 } \\
33\end{array}$ \\
\hline $\begin{array}{l}\text { Remotididymell } \\
\text { a anthropophila }\end{array}$ & $\begin{array}{l}\text { CBS 142462; } \\
\text { UTHSC:DI16- } \\
278 ; \\
\text { FMR } 13770\end{array}$ & $\begin{array}{l}\text { Human } \\
\text { respiratory } \\
\text { tract }\end{array}$ & USA & $\begin{array}{l}\text { LN9074 } \\
21\end{array}$ & $\begin{array}{l}\text { LT5929 } \\
36\end{array}$ & $\begin{array}{l}\text { LT5930 } \\
05\end{array}$ & $\begin{array}{l}\text { LT5930 } \\
75\end{array}$ \\
\hline R. destructival & $\begin{array}{l}\text { CBS 133.93; } \\
\text { FMR } 15349\end{array}$ & $\begin{array}{l}\text { Solanum } \\
\text { lycopersicon }\end{array}$ & Guadeloupe & $\begin{array}{l}\text { GU2380 } \\
64\end{array}$ & $\begin{array}{l}\text { GU2377 } \\
79\end{array}$ & $\begin{array}{l}\text { GU2376 } \\
02\end{array}$ & $\begin{array}{l}\text { LT6232 } \\
57\end{array}$ \\
\hline R. destructiva2 & $\begin{array}{l}\text { CBS 378.73; } \\
\text { FMR } 15328\end{array}$ & $\begin{array}{l}\text { Lycopersicon } \\
\text { esculentum }\end{array}$ & Tonga & $\begin{array}{l}\text { GU2380 } \\
63\end{array}$ & $\begin{array}{l}\text { GU2378 } \\
49\end{array}$ & $\begin{array}{l}\text { GU2376 } \\
01\end{array}$ & $\begin{array}{l}\text { LT6232 } \\
58\end{array}$ \\
\hline R. destructiva3 & $\begin{array}{l}\text { CBS 162.78; } \\
\text { FMR } 14906\end{array}$ & $\begin{array}{l}\text { Lycopersicon } \\
\text { esculentum }\end{array}$ & $\begin{array}{l}\text { The } \\
\text { Netherlands }\end{array}$ & $\begin{array}{l}\text { GU2380 } \\
62\end{array}$ & $\begin{array}{l}\text { GU2377 } \\
88\end{array}$ & $\begin{array}{l}\text { GU2376 } \\
00\end{array}$ & $\begin{array}{l}\text { LT6232 } \\
59\end{array}$ \\
\hline $\begin{array}{l}\text { Similiphoma } \\
\text { crystallifera }\end{array}$ & $\begin{array}{l}\text { CBS 193.82; } \\
\text { FMR } 1534\end{array}$ & $\begin{array}{l}\text { Chamaespartiu } \\
m \text { sagittale }\end{array}$ & Austria & $\begin{array}{l}\text { GU2380 } \\
60\end{array}$ & $\begin{array}{l}\text { GU2377 } \\
97\end{array}$ & $\begin{array}{l}\text { GU2375 } \\
98\end{array}$ & $\begin{array}{l}\text { LT6232 } \\
67\end{array}$ \\
\hline $\begin{array}{l}\text { Stagonosporops } \\
\text { is dorenboschii }\end{array}$ & CBS 426.90 & $\begin{array}{l}\text { Physostegia } \\
\text { virginiana }\end{array}$ & $\begin{array}{l}\text { The } \\
\text { Netherlands }\end{array}$ & $\begin{array}{l}\text { GU2381 } \\
85\end{array}$ & $\begin{array}{l}\text { GU2378 } \\
62\end{array}$ & $\begin{array}{l}\text { GU2376 } \\
90\end{array}$ & $\begin{array}{l}\text { KT3896 } \\
78\end{array}$ \\
\hline S. hortensis & CBS 572.85 & $\begin{array}{l}\text { Phaseolus } \\
\text { vulgaris }\end{array}$ & $\begin{array}{l}\text { The } \\
\text { Netherlands }\end{array}$ & $\begin{array}{l}\text { GU2381 } \\
99\end{array}$ & $\begin{array}{l}\text { GU2378 } \\
93\end{array}$ & $\begin{array}{l}\text { GU2377 } \\
04\end{array}$ & $\begin{array}{l}\text { KT3896 } \\
81\end{array}$ \\
\hline $\begin{array}{l}\text { Vacuiphoma } \\
\text { bulgarica }\end{array}$ & $\begin{array}{l}\text { CBS 357.84; } \\
\text { FMR } 14917\end{array}$ & $\begin{array}{l}\text { Trachystemon } \\
\text { orientale }\end{array}$ & Bulgaria & $\begin{array}{l}\text { GU2380 } \\
50\end{array}$ & $\begin{array}{l}\text { GU2378 } \\
37\end{array}$ & $\begin{array}{l}\text { GU2375 } \\
89\end{array}$ & $\begin{array}{l}\text { LT6232 } \\
56\end{array}$ \\
\hline V. oculihominis & $\begin{array}{l}\text { UTHSC:DI16- } \\
308 ; \\
\text { FMR } 13801\end{array}$ & $\begin{array}{l}\text { Human } \\
\text { superficial } \\
\text { tissue }\end{array}$ & USA & $\begin{array}{l}\text { LN9074 } \\
51\end{array}$ & $\begin{array}{l}\text { LT5929 } \\
54\end{array}$ & $\begin{array}{l}\text { LT5930 } \\
23\end{array}$ & $\begin{array}{l}\text { LT5930 } \\
93\end{array}$ \\
\hline $\begin{array}{l}\text { Xenodidymella } \\
\text { applanata }\end{array}$ & CBS 205.63 & Rubus idaeus & $\begin{array}{l}\text { The } \\
\text { Netherland }\end{array}$ & $\begin{array}{l}\text { GU2379 } \\
98\end{array}$ & $\begin{array}{l}\text { GU2377 } \\
98\end{array}$ & $\begin{array}{l}\text { GU2375 } \\
56\end{array}$ & $\begin{array}{l}\text { KP3304 } \\
02\end{array}$ \\
\hline X. asphodeli & CBS 375.62 & $\begin{array}{l}\text { Asphodelus } \\
\text { albus }\end{array}$ & France & $\begin{array}{l}\text { KT3897 } \\
65\end{array}$ & $\begin{array}{l}\text { KT3895 } \\
49\end{array}$ & $\begin{array}{l}\text { KT3898 } \\
53\end{array}$ & $\begin{array}{l}\text { KT3896 } \\
89\end{array}$ \\
\hline$X$. catariae & CBS 102635 & $\begin{array}{l}\text { Nepeta } \\
\text { catenaria }\end{array}$ & $\begin{array}{l}\text { The } \\
\text { Netherlands }\end{array}$ & $\begin{array}{l}\text { GU2379 } \\
62\end{array}$ & $\begin{array}{l}\text { GU2377 } \\
27\end{array}$ & $\begin{array}{l}\text { GU2375 } \\
24\end{array}$ & $\begin{array}{l}\text { KP3304 } \\
04\end{array}$ \\
\hline X. humicola & CBS 220.85 & Franseria sp. & USA & $\begin{array}{l}\text { GU2380 } \\
86\end{array}$ & $\begin{array}{l}\text { GU2378 } \\
00\end{array}$ & $\begin{array}{l}\text { GU2376 } \\
17\end{array}$ & $\begin{array}{l}\text { KP3304 } \\
22\end{array}$ \\
\hline
\end{tabular}

1 Abbreviation of culture collections: CBS: Centraalbureau voor Schimmelcultures, Utrecht, The Netherlands; CGMCC: China General Microbiological Culture Collection, Beijing, China; CPC: Culture collection of Pedro Crous, housed at CBS; FMR, Facultatde Medicina, Universitat Rovirai Virgili, Reus, Spain; ICMP: International Collection of Microorganisms from Plants, Auckland, New Zealand; IMI: International Mycological Institute, CABI-Bioscience, Egham, Bakeham Lane, IRAN: Iranian Fungal Culture Collection, Iranian Research Institute of Plant Protection, Iran; U.K.; LC: Cultur collection of Qian Chen, housed at CAS, China; MFLUCC: Mae Fah Luang University Culture Collection, Chiang Rai, Thailand; PD: Plant Protection Service, Wageningen, the Netherlands; UTHSC, Fungus Testing Laboratory at the University of Texas Health Science Center, San Antonio, Texas, USA.

Supplementary table 3 The divergence time of the nodes in different study

\begin{tabular}{lllllll}
\hline Node & This study & $\begin{array}{l}\text { Beimforde } \\
\text { et al. (2014) }\end{array}$ & $\begin{array}{l}\text { Prieto \& } \\
\text { Wedin }(\mathbf{2 0 1 3})\end{array}$ & $\begin{array}{l}\text { Gueidan } \\
\text { et al. (2011) }\end{array}$ & $\begin{array}{l}\text { Phukhamsakda } \\
\text { et al. (2016) }\end{array}$ & $\begin{array}{l}\text { Pérez-Ortega } \\
\text { et al. (2016) }\end{array}$ \\
\hline DOT & 144.5 & 350 & 174 & 338 & 293 & 290 \\
& $(107-202.9)$ & $(273-459$ & $(107-204)$ & & $(213-371)$ & \\
DID & $\begin{array}{l}35.7 \\
(18.4-63.5)\end{array}$ & - & - & - & - & - \\
& & & & & \\
\hline
\end{tabular}




\section{Supplementary table 3}

\begin{tabular}{lllllll}
\hline Node & This study & $\begin{array}{l}\text { Beimforde } \\
\text { et al. (2014) }\end{array}$ & $\begin{array}{l}\text { Prieto \& } \\
\text { Wedin }(\mathbf{2 0 1 3})\end{array}$ & $\begin{array}{l}\text { Gueidan } \\
\text { et al. (2011) }\end{array}$ & $\begin{array}{l}\text { Phukhamsakda } \\
\text { et al. (2016) }\end{array}$ & $\begin{array}{l}\text { Pérez-Ortega } \\
\text { et al. (2016) }\end{array}$ \\
\hline PLE & 86.7 & - & - & - & 211 & - \\
& $(53.9-155.4)$ & & & & $(153-277)$ & \\
CAP & 99 & - & - & - & 147 & - \\
& $(99-100)$ & & - & - & $392-202)$ & \\
AIG & 34.1 & - & - & - & $(35-49)$ & - \\
& $(34-64.4)$ & & & & & \\
\hline
\end{tabular}

Supplementary table 4 Time chart of the nodes based on the estimated crown age in the current study*

\begin{tabular}{|c|c|c|c|c|}
\hline Period & Epoch & Stage & Age & Taxa \\
\hline \multirow[t]{25}{*}{ Quaternary } & Holocene & & $0-0.012$ & \\
\hline & Pleistocene & Late & $0.012-0.126$ & Briansuttonomyces \\
\hline & & Middle & $0.126-1.8$ & Neomicrosphaeropsis; \\
\hline & & & & Phoma; \\
\hline & & & & Juxtiphoma; \\
\hline & & & & Iranian Neodidymelliopsis; \\
\hline & & & & Pseudoascochyta \\
\hline & & Early & $1.8-2.58$ & - \\
\hline & Miocene & Late & $5.33-11.63$ & Paraboeremia; \\
\hline & & & & Leptosphaerulina; \\
\hline & & & & Allophoma; \\
\hline & & & & Ascochyta; \\
\hline & & & & Heterophoma; \\
\hline & & & & Stagonosporopsis; \\
\hline & & & & Epicoccum; \\
\hline & & & & Remotididymella; \\
\hline & & & & Vacuiphoma; \\
\hline & & & & Nothophoma; \\
\hline & & & & Neodidymelliopsis; \\
\hline & & Middle & $11.63-16$ & Calophoma; \\
\hline & & & & Didymella; \\
\hline & & & & Neoascochyta; \\
\hline & & & & Similiphoma; \\
\hline & & & & Xenodidymella; \\
\hline & & Early & $16-23.03$ & - \\
\hline \multirow[t]{7}{*}{ Paleogene } & Oligocene & Late & $23.03-27.82$ & - \\
\hline & & Early & $27.82-33.9$ & \\
\hline & Eocene & Late & $33.9-37.8$ & Aigialus; \\
\hline & & & & Didymellaceae \\
\hline & & Middle & $37.8-47.8$ & \\
\hline & & Early & $47.8-56$ & \\
\hline & Paleocene & & $56-66$ & \\
\hline \multirow[t]{3}{*}{ Cretaceous } & & & $66-147.5$ & Pleosporales; \\
\hline & & & & Capnodiales; \\
\hline & & & & Dothideomycetes \\
\hline
\end{tabular}


*The geological time scales were retrieved from the International Commission on Stratigraphy (ICS) website (www.stratigraphy.com)

Supplementary table 5 Time chart of the nodes based on the estimated stem age in the current study*

\begin{tabular}{|c|c|c|c|c|}
\hline Period & Epoch & Stage & Age & Taxa \\
\hline \multirow{2}{*}{ Quaternary } & Holocene & & $0-0.012$ & \\
\hline & Pleistocene & Late & $0.012-2.58$ & - \\
\hline \multirow[t]{12}{*}{ Neogene } & Pliocene & & $2.58-5.33$ & $\begin{array}{l}\text { Iranian Neodidymelliopsis- } \\
\text { Neodidymelliopsis }\end{array}$ \\
\hline & Miocene & Late & $5.33-11.63$ & $\begin{array}{l}\text { Briansuttonomyces } \\
\text { Pseudoascochyta } \\
\text { Iranian Didymella-Didymella } \\
\text { Allophoma } \\
\text { Heterophoma } \\
\text { Ascochyta } \\
\text { Phomatodes }\end{array}$ \\
\hline & & Early & $16-23.03$ & Remotididymella \\
\hline & & & & Phoma \\
\hline & & & & Similiphoma \\
\hline & & & & Macroventuria \\
\hline & & & & Didymella \\
\hline & & & & Nothophoma \\
\hline & & & & Calophoma \\
\hline & & & & Juxtiphoma \\
\hline & & & & Leptosphaerulina \\
\hline & & & & Vacuiphoma \\
\hline \multirow[t]{6}{*}{ Paleogene } & Oligocene & Late & $23.03-27.82$ & $\begin{array}{l}\text { Xenodidymella } \\
\text { Neodidymelliopsis }\end{array}$ \\
\hline & & Early & $27.82-33.9$ & - \\
\hline & Eocene & Late & $33.9-37.8$ & Neoascochyta \\
\hline & & Middle & $37.8-47.8$ & - \\
\hline & & Early & $47.8-56$ & - \\
\hline & Paleocene & & $56-66$ & \\
\hline Cretaceous & & & $66-147.5$ & $\begin{array}{l}\text { Aigialus- Didymellaceae } \\
\text { Pleosporales- Capnodiales }\end{array}$ \\
\hline
\end{tabular}

*The geological time scales were retrieved from the International Commission on Stratigraphy (ICS) website (www.stratigraphy.com) 


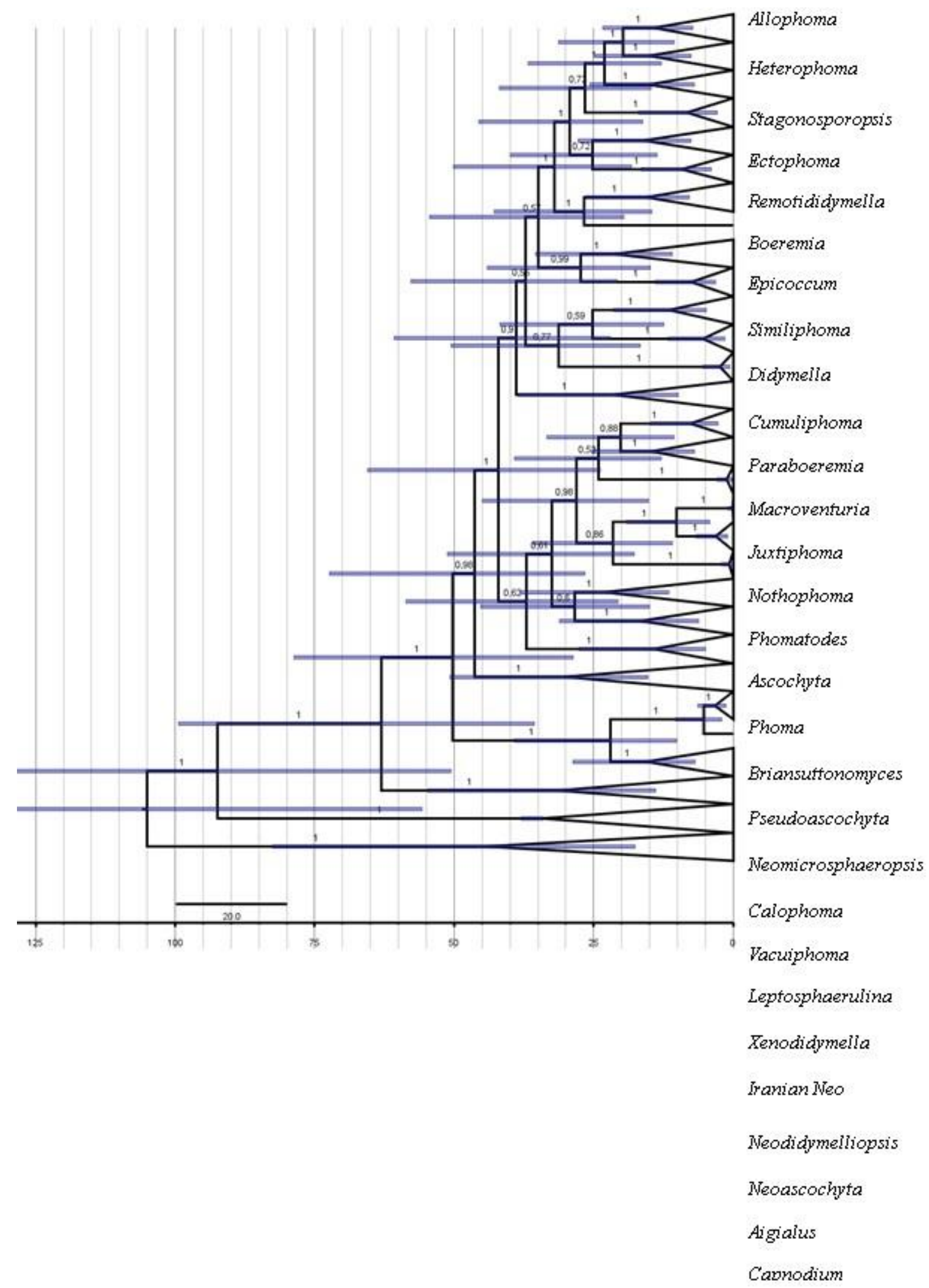

Supplementary figure 1 - Dated phylogenetic tree of scenario I. The numbers next to the nodes indicate posterior probability values. 


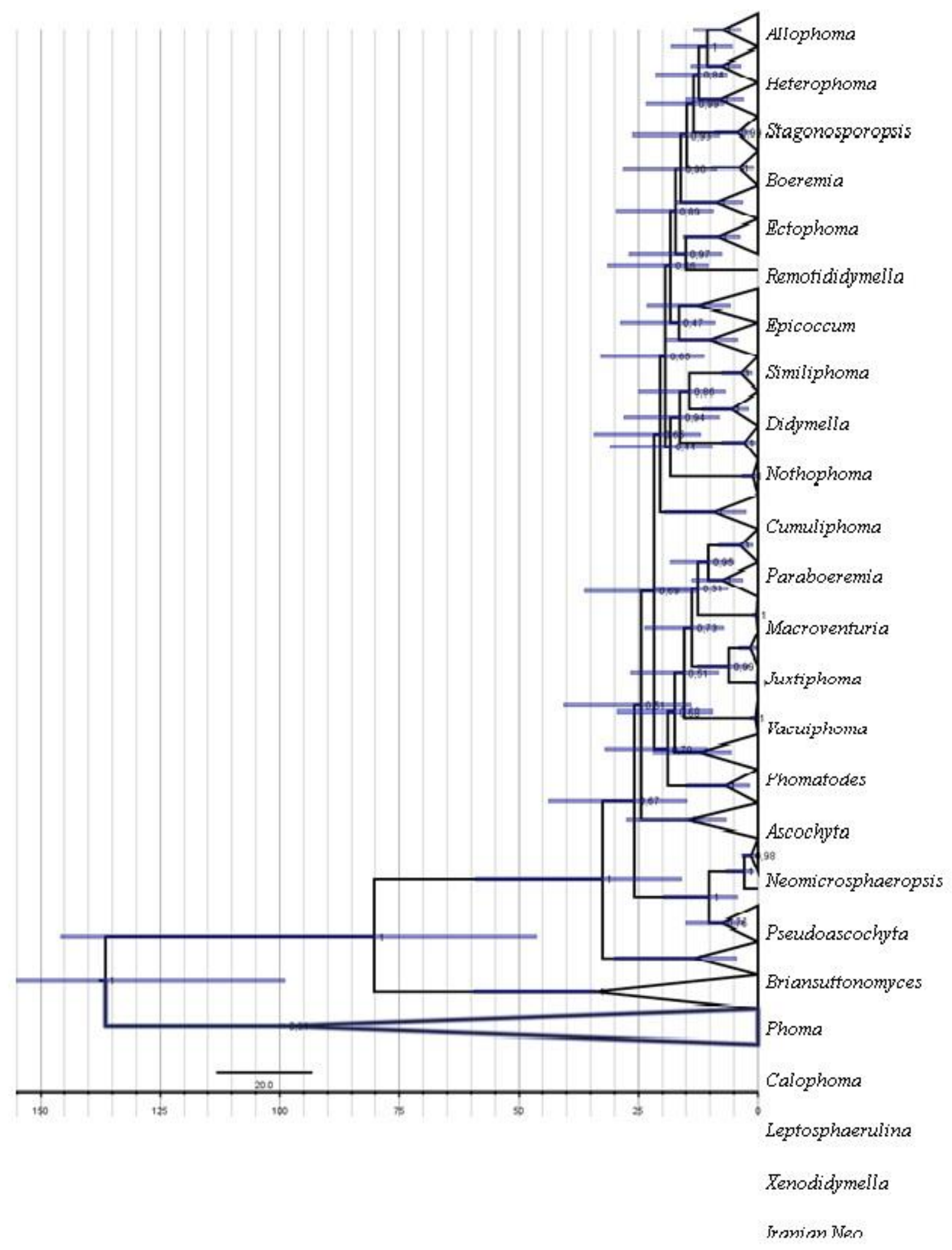

Supplementary figure 2 - Dated phylogenetic tree of scenario II. The numbers next to the nodes indicate posterior probability values. 


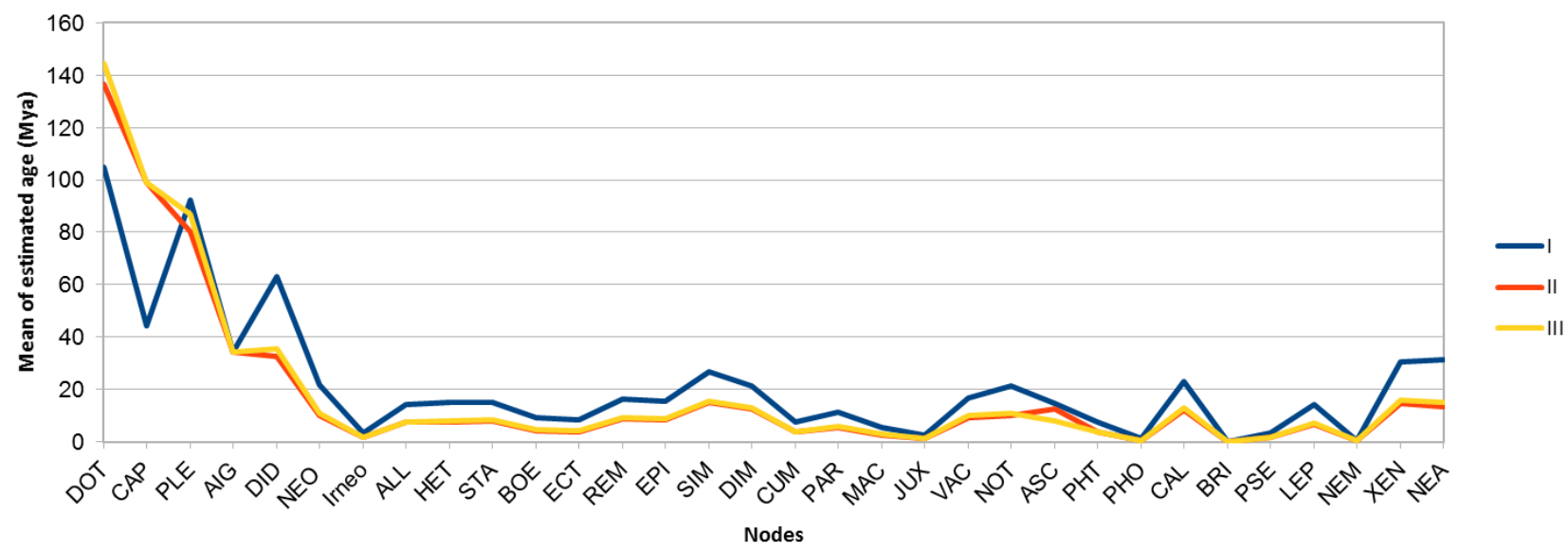

Supplementary figure 3 - The means of estimated age of different nodes in scenario I (blue), II (red) and III (yellow) 